\title{
النبوة في القرآن الكريم: \\ دراسة في التأصيل المقاصدي والحاجة البشرية
}

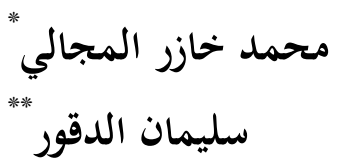

$$
\begin{aligned}
& \text { الملخص } \\
& \text { يتناول هذا البحث دراسة "النبوة" من حيث مفهومها ودلالات ورودها في الاستعمال القرآي، مقارنة بمصطلح } \\
& \text { "الرسالة".ويقوم على دراسة هذا الاستعمال القرآي مؤصلاً المقاصد العامة الكلية التي رسمها القرآن لدور النبوة، وما } \\
& \text { يتصل بها من علائق الوحي، ومدى حاجة الناس إلى إرث هذه النبوة، ومحاولة ربطها بواقعنا المعاصر للكشف عن } \\
& \text { مقاصد شرعية ترشد إلى أهمية تمسك المسلم والناس جميعا بالوحي. } \\
& \text { ويسعى البحث إلى الكشف عن مقاصد القرآن الكريم الأساسية في حديثه عن النبوة وأثرها، وبيان أهمية النبوة } \\
& \text { ودورها في تحقيق صلة إيمان الخلق بالخالق، وإثبات مدى حاجة الناس جميعا إلى النبوة في أثرها المتعلق بوحي القرآن } \\
& \text { والسنة. } \\
& \text { الكلمات المفتاحية: النبوة، الوحي، الرسالة، مقاصد النبوة، مقاصد الوحي، الحاجة إلى النبوة. }
\end{aligned}
$$

\section{Prophethood in the Qur'an: A Study on building foundations of Intents and Human Need}

\section{Abstract}

This article discusses 'Prophethood', its concept and meanings given to it in the Qur'an in comparison with the concept of "Message". The study takes into consideration the general intents which the Qur'an has put forth for the role of Prophethood and its relation to revelation, and to what extent people are in need of the legacy of Prophethood. The article highlights Qur'an's basic intents when talking about Prophethood, clarifies its importance in strengthening the bond with the Lord, and demonstrating the real need for Prophethood in the revelation of Qur'an and Sunnah.

Keywords: Prophethood, Revelation, Message, Prophethood intents, the need for Prophethood.

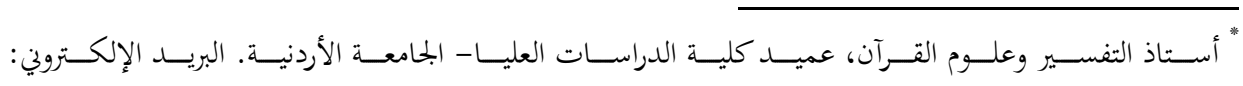

$$
\begin{aligned}
& \text { mkmajali@hotmail.com }
\end{aligned}
$$

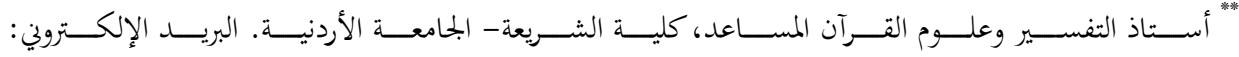

$$
\begin{aligned}
& \text { s.dgoor@hotmail.com }
\end{aligned}
$$

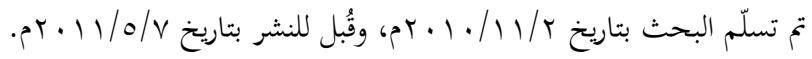




\section{مقدمة:}

الوحي مسألة مهمة في كل الأديان، ويُعَدُّ الإيمان به ركنًا أساسيًا في الاعتقاد. وهو الوسيلة التي من خلالما يبلِّغ الله رسالَه للناس، ويقيم عليهم الحجة به، وهو صلة السماء بالأرض، ورحمة الله ولطفه بعباده، وبهذا يمكننا إدراك أهمية الوحي للإنسانية كلها، وأهمية ما يتصل به من قيم الرسالة والنبوة.

وحاجـة النـاس إلى الشـريعة تفـوق حـاجتهم إلى الطعام والشـراب، يقول ابن القيم:

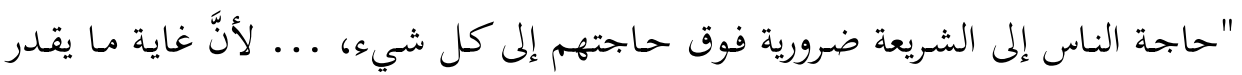

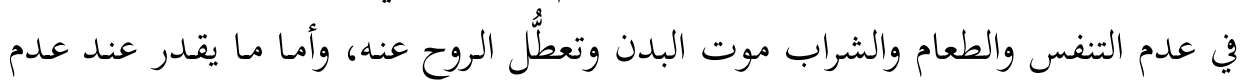

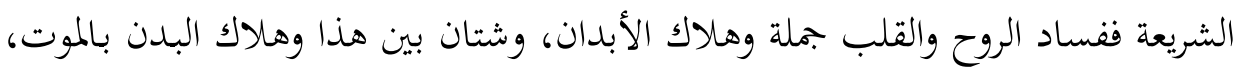

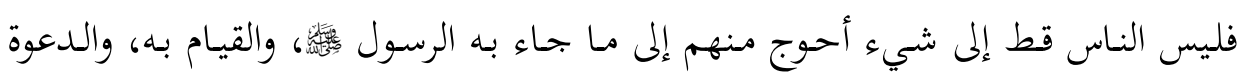

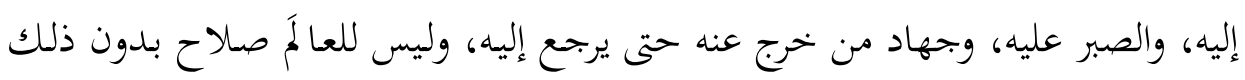

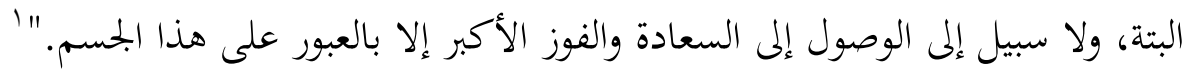
فالوحي والنبوة هما الوسيلة التي أراد الله بهما تبليغ البشرية دينها ومنهج حياتا، لتسير في هذه الحياة على هدى ونور، بلا تخبط ولا ضلال، وصدق الله العظيم وهو يبين

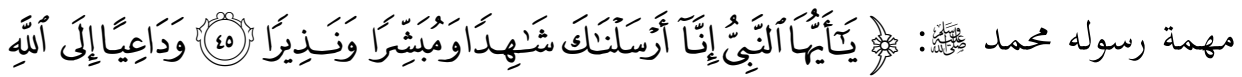

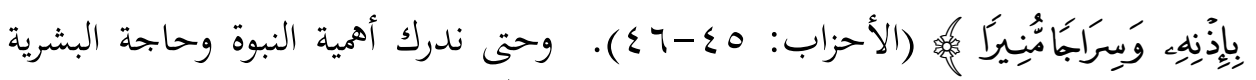

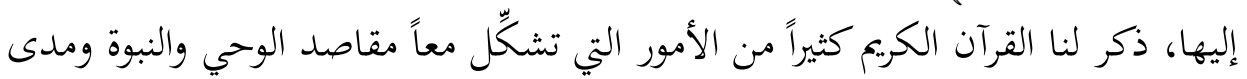

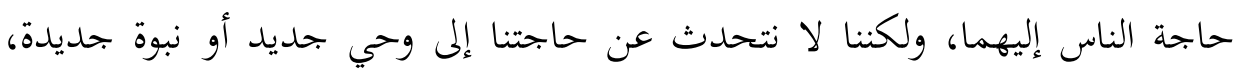

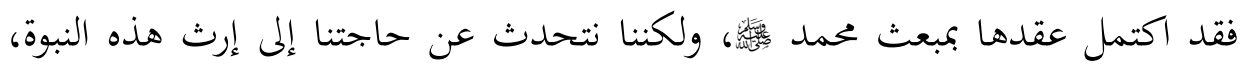
وإدراك فلسفتها ودورها ومقاصدها التي تحدد وجهة الإنسان، قال تعالى:

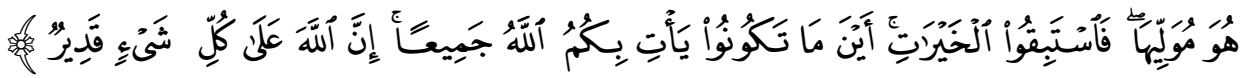

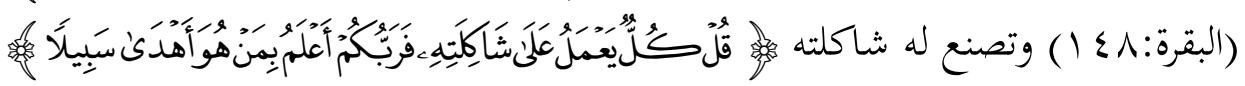
(الإسراء: ع) وهذا ما سنلقي عليه الضوء في بحثنا هذا إن شاء الله. ' ابن قيم الجوزية. مفتاح دار السعادة، بيروت: دار الكتب العلمية، طا، ال. بـم، جr، صץ. 
وقد اتبعنا المنهج الاستقرائي لاستقراء آيات القرآن الكريم المتعلقة بالموضوع، والمنهج

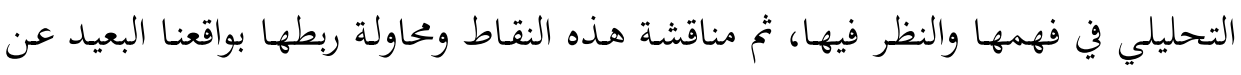

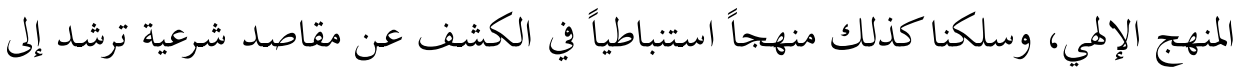

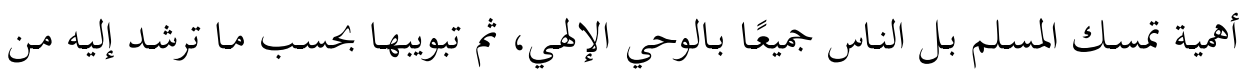

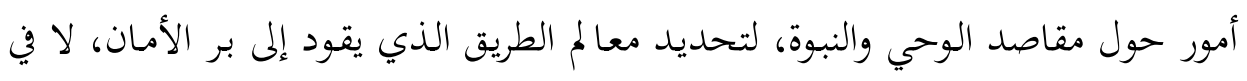
الدنيا فحسب، بل في الحياة الباقية القادمة.

وقد يكون من اللافت لانتباه القارئ الكريم أنَّ موضوع النبوة وما يتصل بها هو من

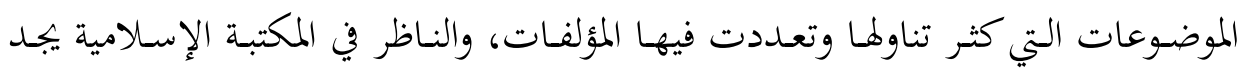
ذلك واضحاً جلياً.

غير أنَّ ما يجب تأكيده هنا لصالح إبراز قيمة هذا البحث فيما يعطيه من بعد جديد

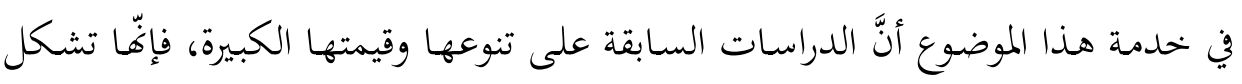

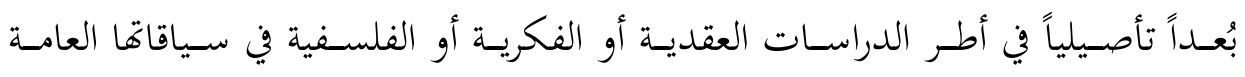

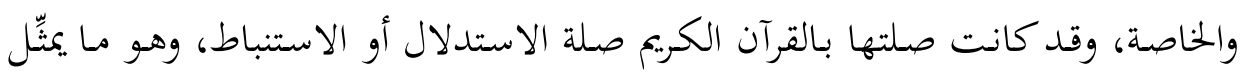

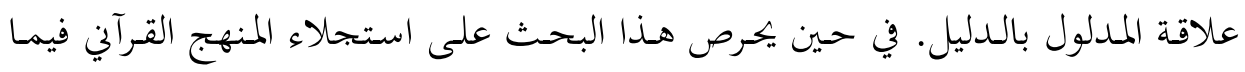

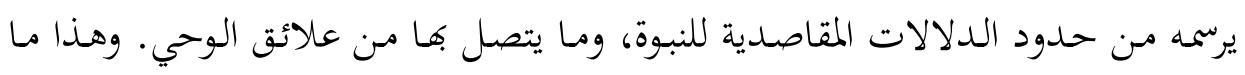

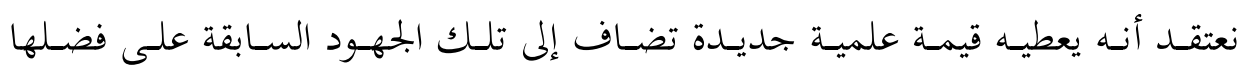
ومكانتها.

ولأنَّان نريد البحث في المقاصد القرآنية العامة التي ذكرها لهذا الغرض، فقد وجدانا من

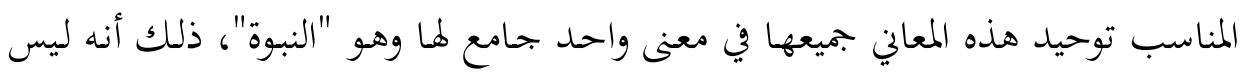

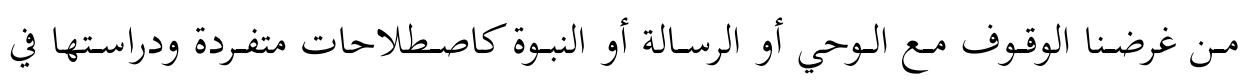

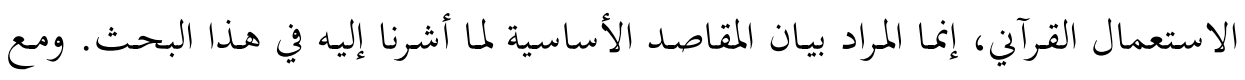

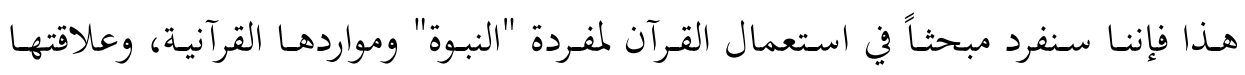
بمفردة "الرسالة"، بقصد التأصيل للاستعمال القرآين. 


\section{أولاً: "النبوة" و"الرسالة" المفهوم والدلالات القرآنية}

\section{1 ا بـ الدلالة اللغوية والشرعية:}

كثيراً مـا بحد اختلافاً في تحديدات العلماء لمعنى النبوة والرسالة، وباعث ذلك هو الاختتلاف في تحديد الدلالات اللغوية مـن جهة، والدقة في تحديد الاستعمال القرآني

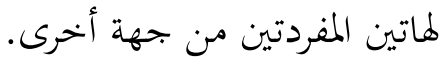

فالنبوة مأخوذة من النَّبأ، وهو الخبر، ولذلك فقد وردت في كلمة (نبي) قراءة أخرى

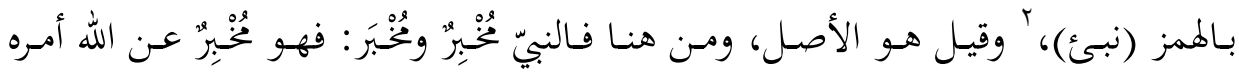

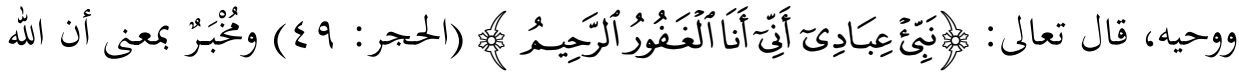

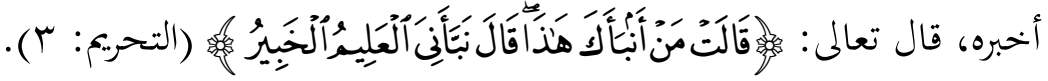

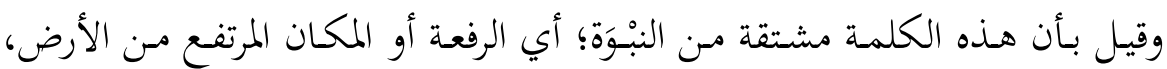

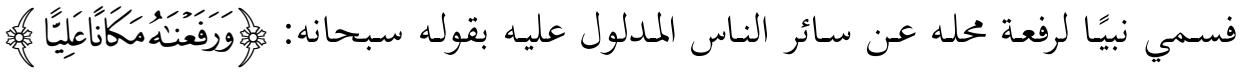

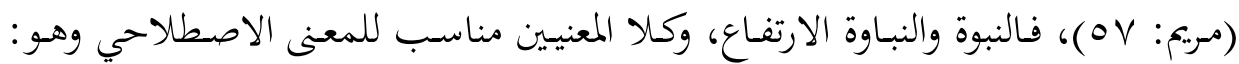
اصطفاء الله عبدًا من عباده بالوحي إليه.

أمـا الرسالة فهي مـ الإرسال الذي هو التوجيه، قال تعالى حاكياً عمّن أرسلتهم

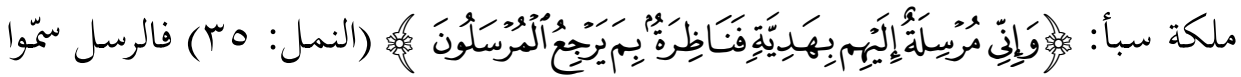

r وهي قراءة نافع بالهمز، انظر هذه الكلمة حيثما وردت في القرآن، في كتب القراءات ومنها:

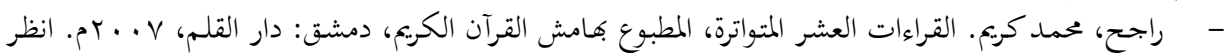

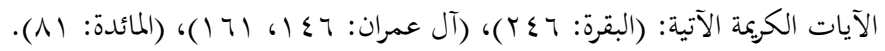

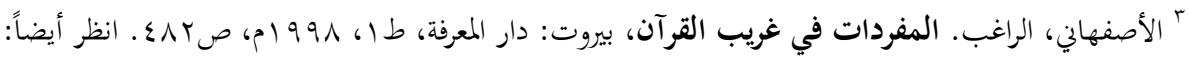

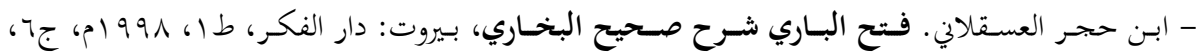

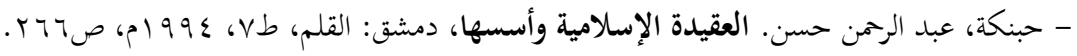

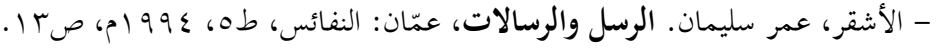

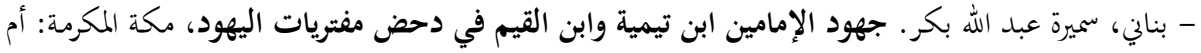

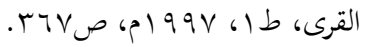




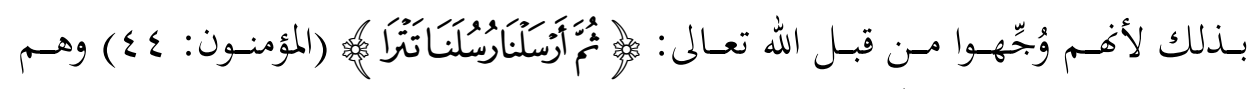

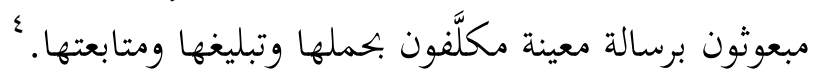

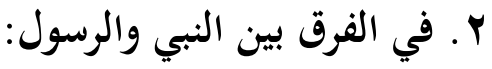

وسوف نعرض هنا صورة توصيفية لخلاصة ما ذكر في معنى اللفظتين لنحدد بعد

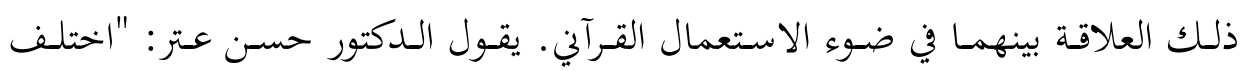
العلماء في الفرق بين الأنبياء والرسل على قولين رئيسيين:

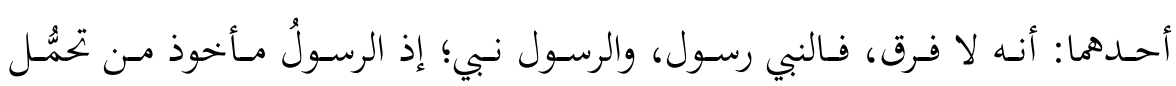

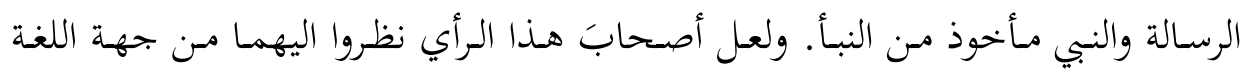
فحسب، فعدُّوا الرسول اسم مفعول والنبي اسم فاعل، فلم يجدوا فرقاً فسووا بينهما.

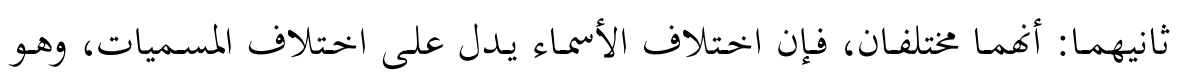

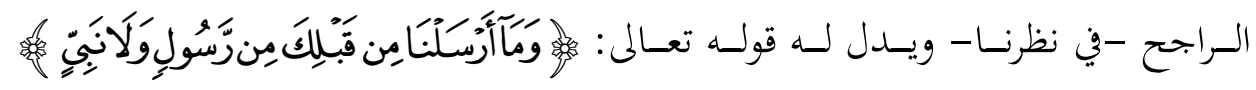
(الحج: Or ) فإن عطف نبي على رسول يدل على على المغايرة بينهما." وقد انصرف أصحاب هذا الرأي في تحديد الفرق بين النبي والرسول إلى أقوال: الأول: أن الرسول مَن بعثه الله تعالى بشرع جديد، والنبي يعمّه، ومن بعثه الله لتقرير شرع سابق. الثاني: أن الرسول مسن بعثه الله إلى قوم بشرع جديد بالنسبة إليهم، وإن لم يكن

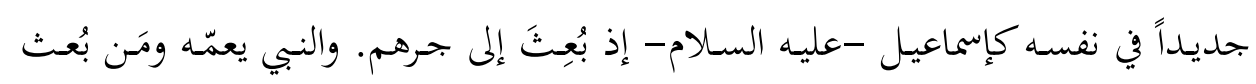
بشرع غير جديد كذلك.

الثالث: إن الرسولَ مـن لـه تبليغ في الجملة وإن كان بياناً وتفصيلاً لشـرع سابق. والنبي من أوحي إليه ولم يؤمر بتبليغ أصلاً.

؛ الأشقر. . الرسل والرسالات، مرجع سابق، صع الـ النظر أيضاً:

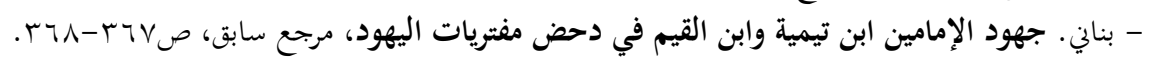




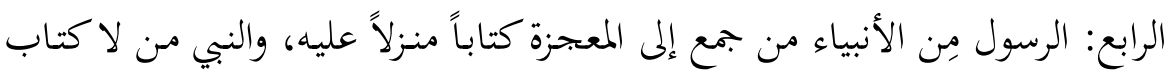

الخامس: الرسول من له كتاب أو نسخ في الجملة، والنبي من لا كتاب له ولا نسخ.

السادس: أن الرسول من يأتيه الملك بالوحي يقظة والنبي من يأتيه الوحي ولو مناماً.

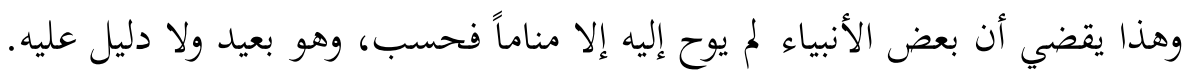
وذهب جماهير العلماء إلى أن الرسول من أوحي إليه وأمر بتبليغ الأحكام، وإن النبي

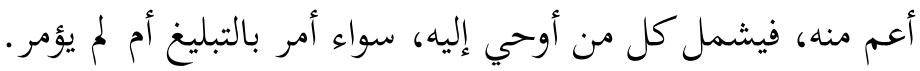

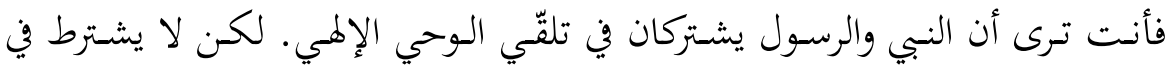
النبي أن يؤمر بالتبليغ، فالنسبة بينهما العموم والخصوص النصوس المطلق.

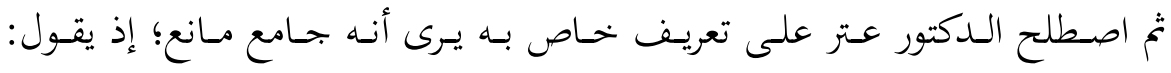

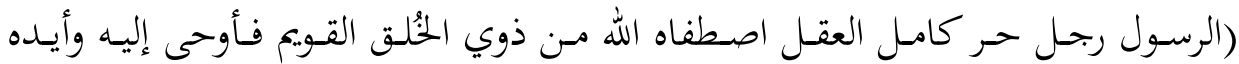

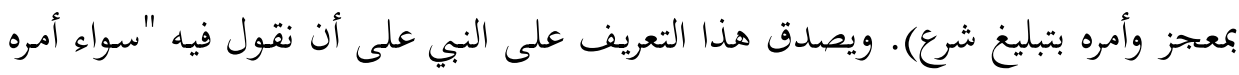
بتبليغ شرع أو لم يأمره."

وهذا التفريق هو الحق في رأينا. وهو أسلم الأقوال وأبعدها عن الاعتراضات التي ترد

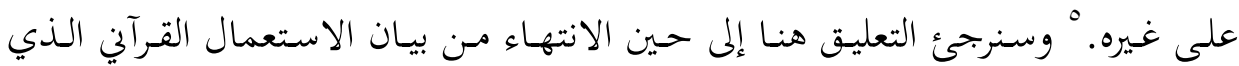
سيجلي لنا المسألة بوضوح.

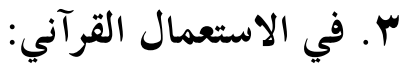

لما لم يكن من هدف البحث أو منهجه التأصيل الموضوعي للاستعمال القرآين، بما

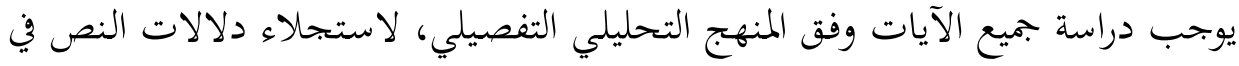

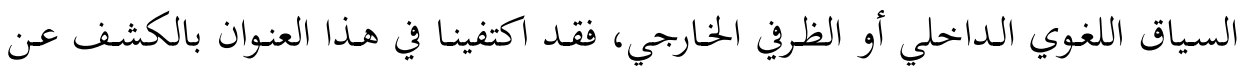

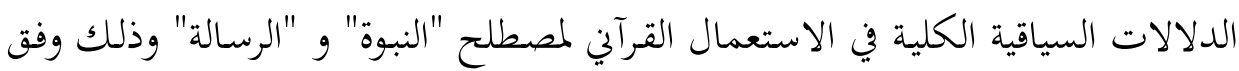

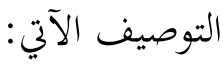


أ. أنبوة في الاستعمال القرآني: - إن

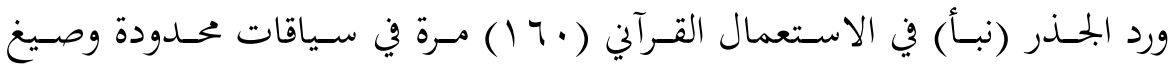

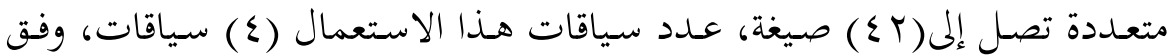

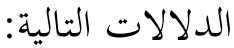

- النبأ بمعنى الخبر ذي الفائدة العظيمة التي يحصل به علمم أو غلبة ظن، وورد في

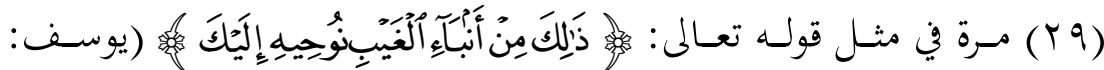

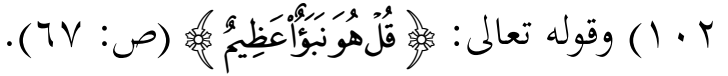

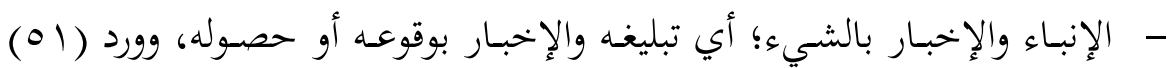

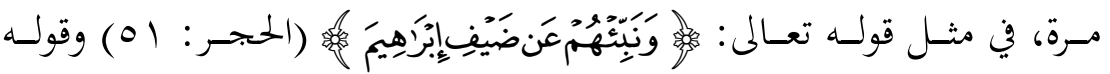

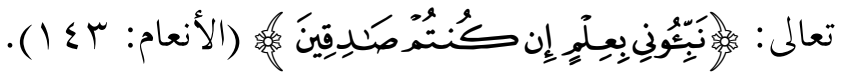
- كل منبأ رفيع القدر والمكانة، وهو من يبعث بالخبر، وورد هذا المعنى (V0) مرة،

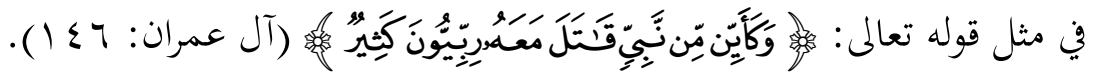
- كل منبأ رفيع القدر والمكانة، وهو من يبعث بالخبر، وورد هذا المعنى (V0) مرة،

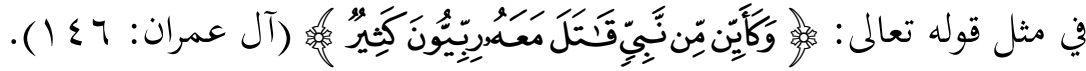

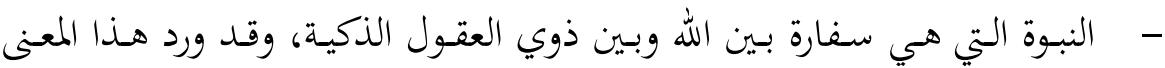

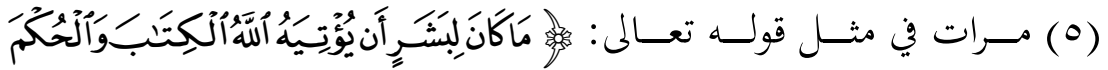

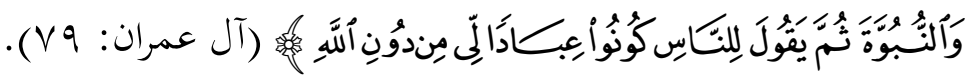
ويظهر لنا من الترتيب الذي جاءت فيه هذه الآيات الخمس المشتملة على "النبوة

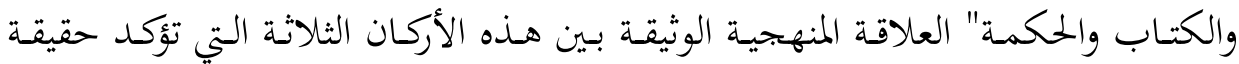
الوحي والرسالة المتشكلة مـ: النبوة: التي هي التشريف بالتكليف لتبليغ أمر الوحي.

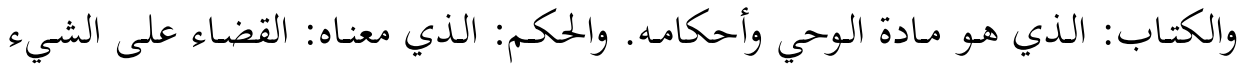
بالشيء، بأن ذلك محتاج إلى الحكمة والقوة والعزم. 


\section{ب. "الرسالة" في الاستعمال القرآني:}

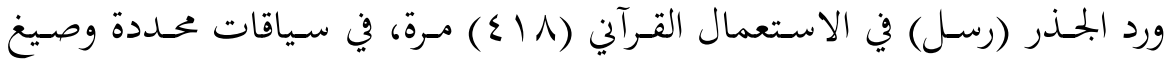

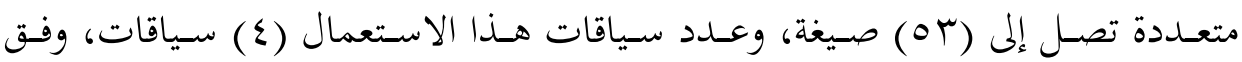

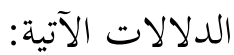

- البعث بالشيء وهو مقابل الإمساك، وورد هذا المعنى (ب) مرة في مثل قوله

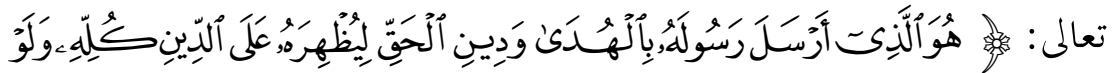

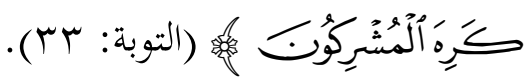
- - والإرسال يكون: للإنسان، ولأشياء المحبوبة؛ كإرسال الملائكة والمطر، ولأشياء

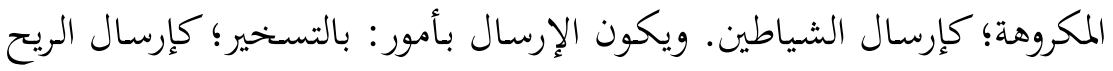

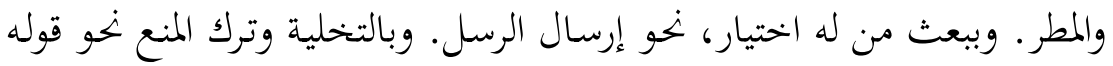

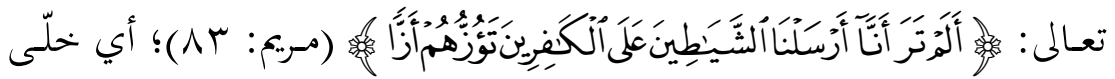

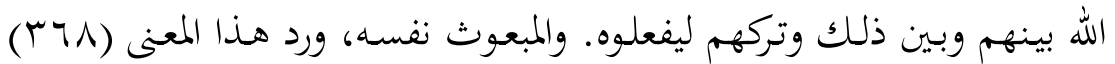

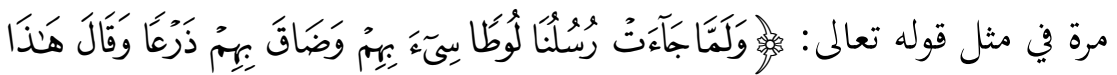

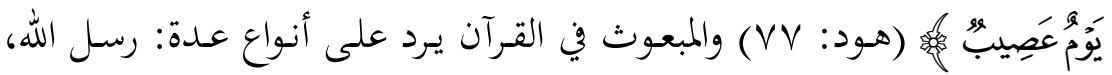

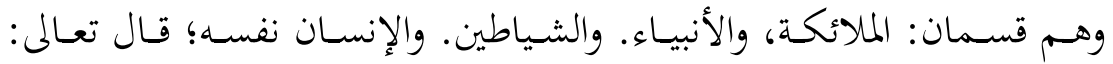

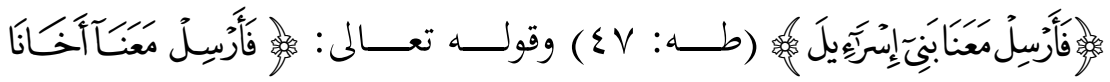

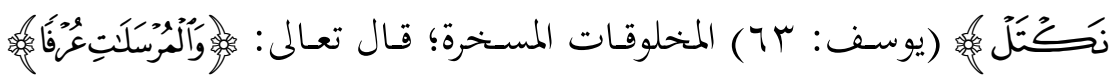

$$
\text { (المرسلات: (1) }
$$

- - مـن قـام بالبعـث أو أمـر بـه، وورد هـذا المعتى (0) مـرات في مثـل قوله تعـالى:

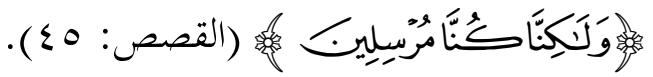

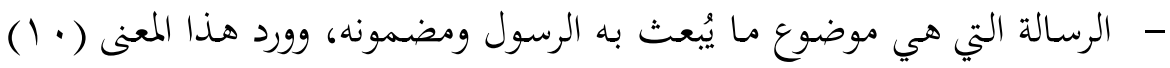

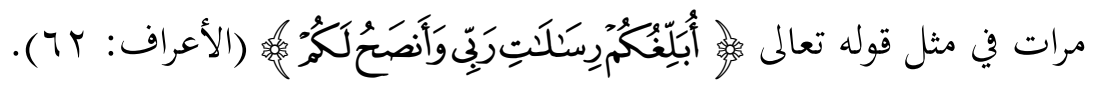




\section{ت. أبعاد ودلالات}

ورد في الاستعمال القرآني تقرير مفهوم خاص (للنبوة) ومفهوم خاص (للرسالة)، ويظهر ذلك من خهلال هذا التنوع وتعدد سياقات كل مفردة من هاتين المفردتين. كما

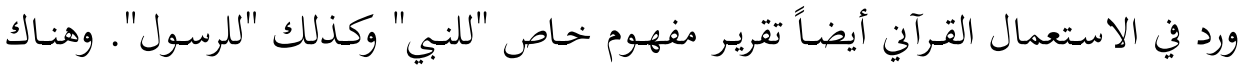
سياقات محددة تبين أنواعاً للاشتراك بين دلالة هاتين اللفظتين وذلك على النحو الآتي:

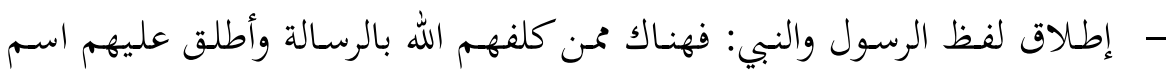
"الرسول" فحسب مثل نوح عليه السلام.

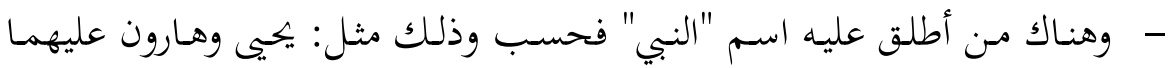
السلام. - مهنالك من أطلق عليه اسم "الرسول" و "النبي" معاً، وذلك مثل: موسى عليه

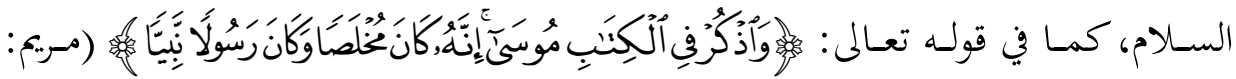

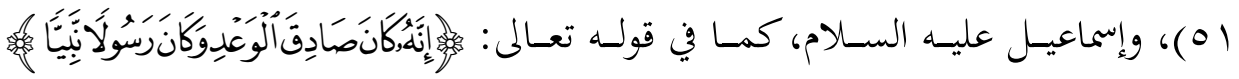

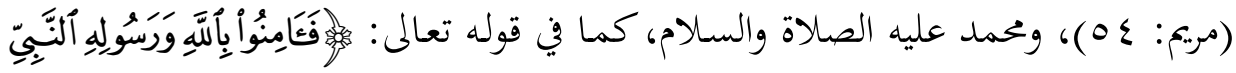

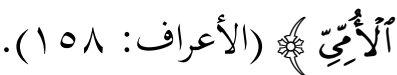
- إطـلاق الفعـل "أرسـل": في حـال إرسـال الرسـول والنبي، كمـا في قولـه تعـالى:

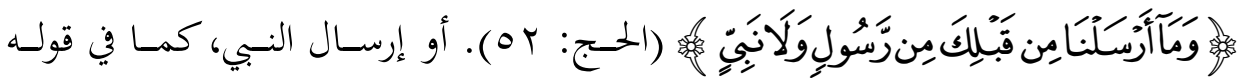

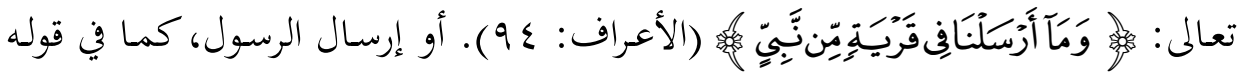
تعالى: والنبي كذلك مرسل.

وهناك بُعد واضح في دلالة لفظتي "النبي" و "الرسول" في الاستعمال القرآني، يظهر من خحلال الاستقراء، ويمكن تحديد ذلك من خحلال بعدين اثنين: البعد الأول: أن هاتين الكلمتين إذا افترقتا في موردها في الآيات القرآنية اجتمعتا في معنى واحد هو: مـن أوحىى

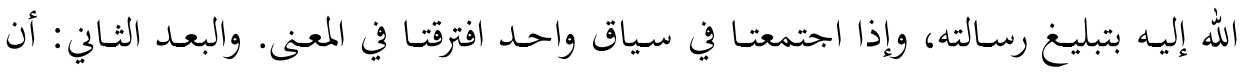
التفريق بينهما في حال الاجتماع يأخذ شكلين اثنين: 
الشكل الأول: اجتماعهما في وصف نبي واحد، في سياق واحد ، كما هو الحال في

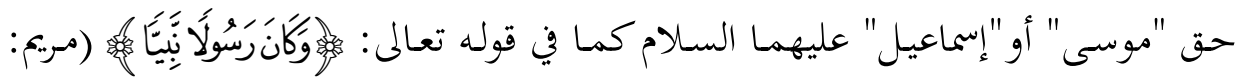

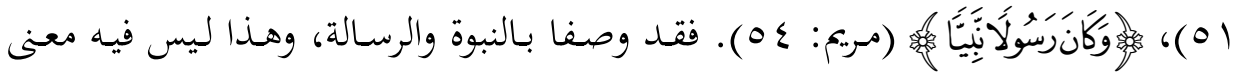
يفيدنا هنا في توضيح دلالتهما القرآنية.

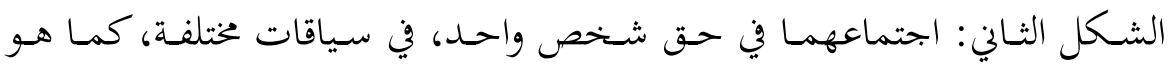

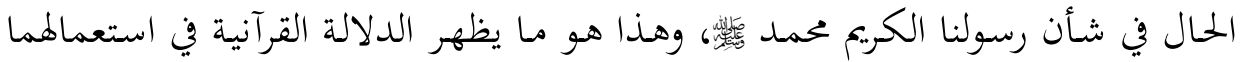

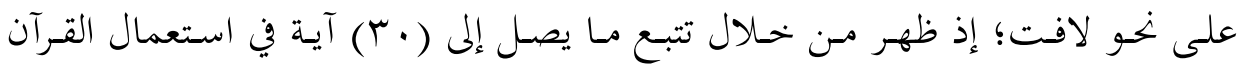

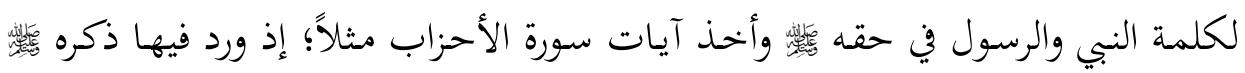

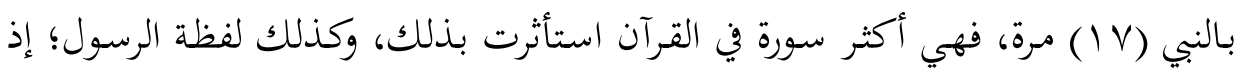

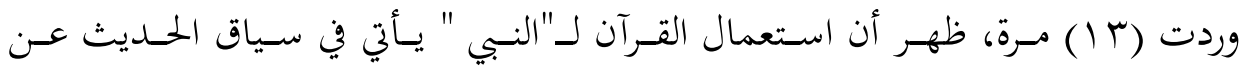

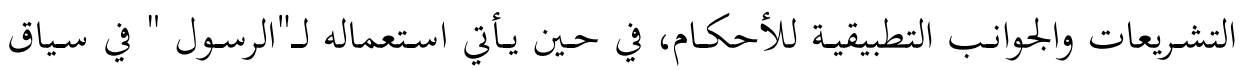
الحديث عن التأصيل والتأسيس لدوره ووظيفته ومكانته.

وفي ظلال ما ذكرنا من معنى النبوة والنبي بدلالة المكان المرتفع والنبأ، ندرك جهتها

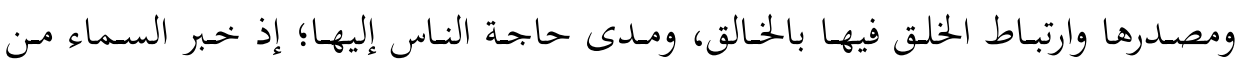

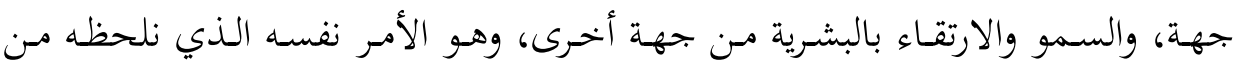

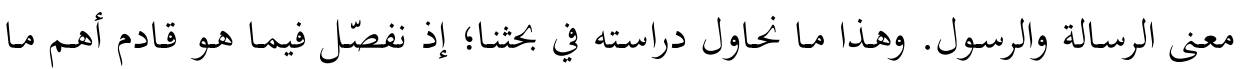

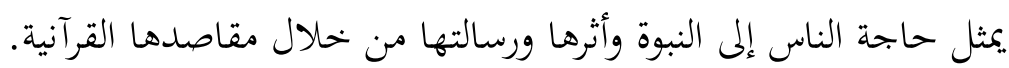

ثانياً: الحاجة إلى النبوة ورسالتها من خلال مقاصدها القرآنية ا ـ النبـوة طريتق لهدايـة البشـرية إلى الإيمـان بـالله ولتحقيق الخيـر والسعادة الحقيقية: - 20 - n

لا شـكّ في أنَّ هـذه هي الغايـة الأسمى والأهـم، وهي التي تنطق بهـا آيـات القرآن

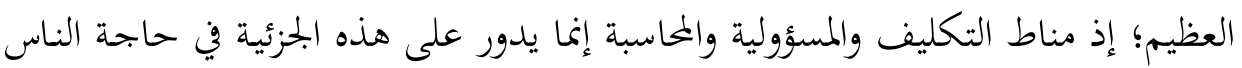


إلى النبوة؛ إذ تبصّرهم بعبادة الله وحـده، ورد النـاس إلى فطرقم التي فطرهم الله عليها،

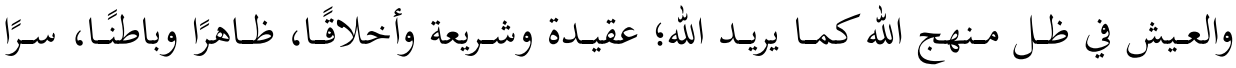

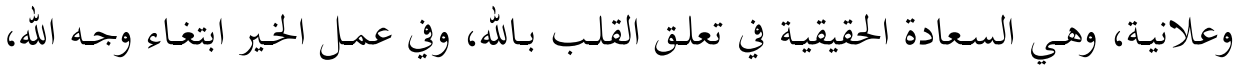

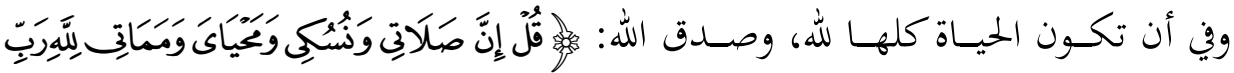

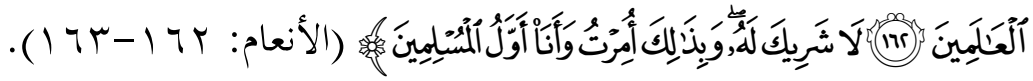
وتتحقـق هدايـة البشرية إلى الإيمـان بـالله في بُعدين اثنـين: البعـد الأول: بنـاء هـذا

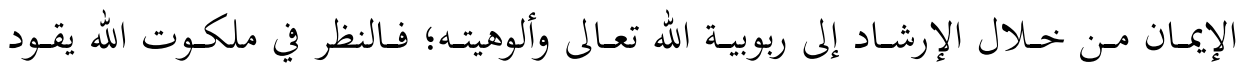
الإنسان إلى التفكر، والتفكر يقود إلى الإيمان الحقق الثابت المنبثق عن قناعة تامة. ولعل

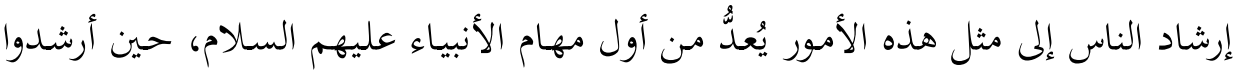

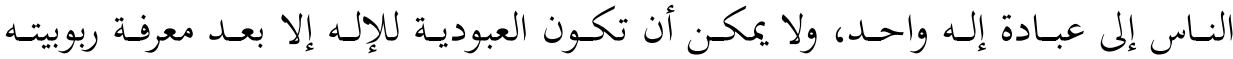

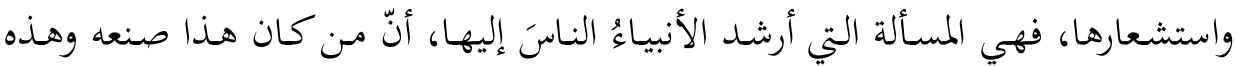
عظمته وهذه دقة خلقه، أيعقل أن يكون هناك خالق غيره ورب غيره ومعبود غيره؟! ولعل النظر في بعض الآيات المكية لا سيّما المتحدثة عن الكون وخلقه، والداعية إلى التفكر في إبداعه وعظمته، تسلم الإنسان إلى الاقتناع بهذه الحقيقة الناصعة. ويمكننا القول إن الصورة بيّنة واضحة أيضًا فيما قصّه الله علينا في القرآن الكريم من

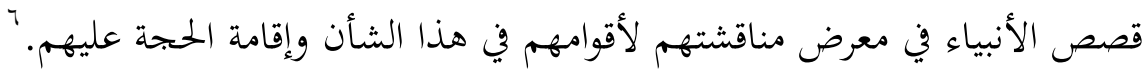
ولا بدّ من أن نذّكّر هنا بضرورة بناء الصلة بين الإيمان بالله من جهة، والإيمان بالأنبياء والرسل من جهة أخرى، فزيادة على أن النبوة طريق للإيمان، فلا يجوز التفريق

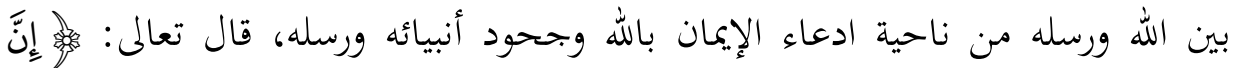

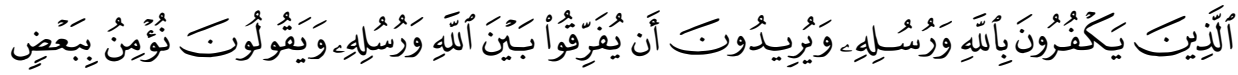

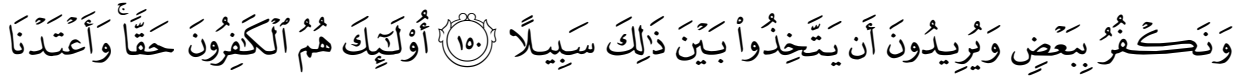

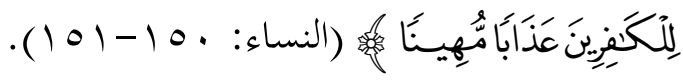

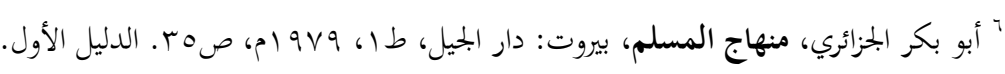


فالآيتان تتحدثان عن كفر أهل الكتاب مـ يهود ونصارى حين كفروا بنبوة محمد ". فهم لم يكفروا في الأصل بكل بالأنبياء والرسل كلهم وبالكتب جميعها، ولكنهم بكفرهم

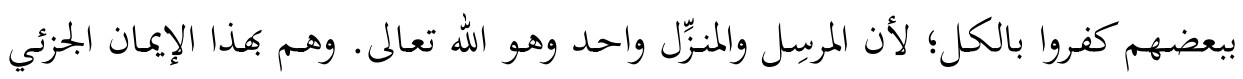

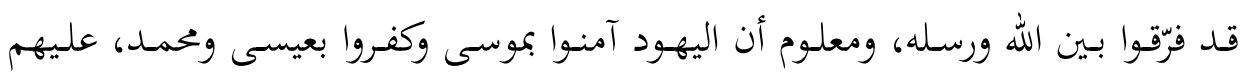

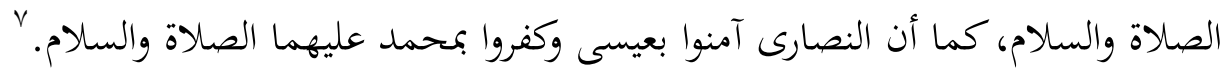

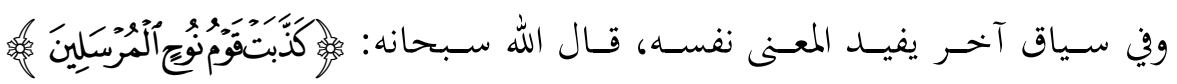

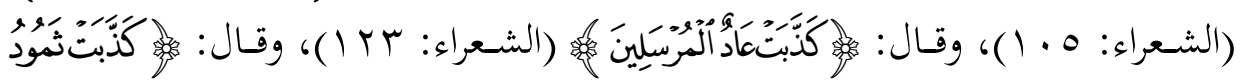

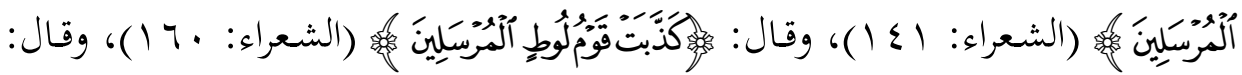

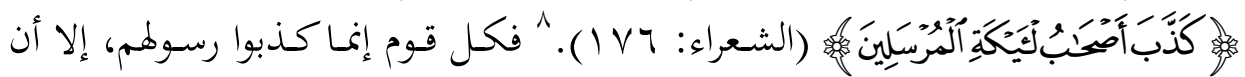
التكذيب بواحد يُعَد تكذيبًا بالجميع. أما البعد الثاني فيتحقق في انعكاس هذه التصورات الإيمانية سلوكاً عبادياً؛ فقد بيّن

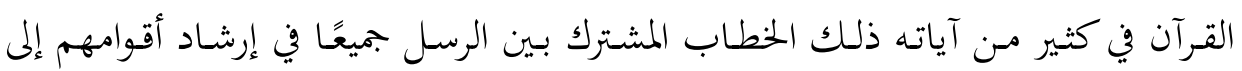

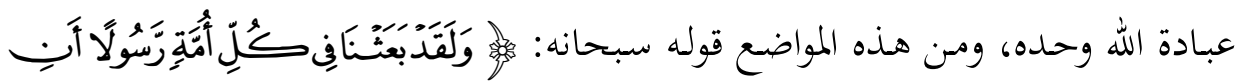

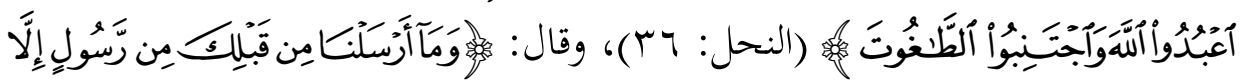

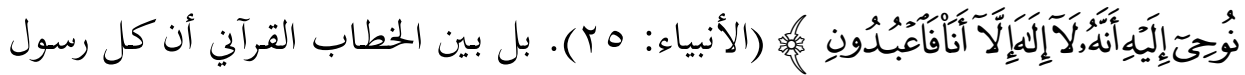

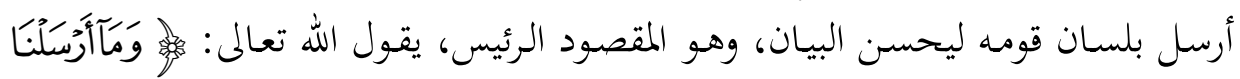

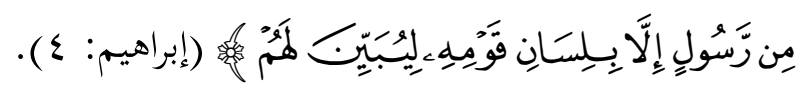

إن للأنبياء ومن تبعهم دورًا مهمًا في ترسيخ العبودية لله، ومسن ثم جلب الخير للبشرية

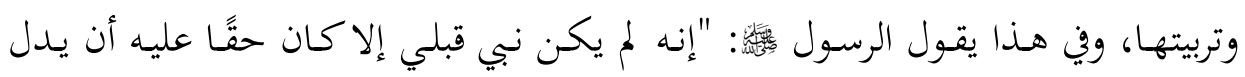

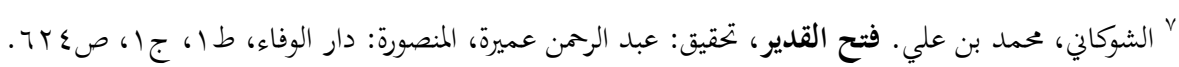

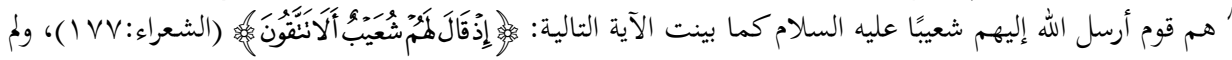

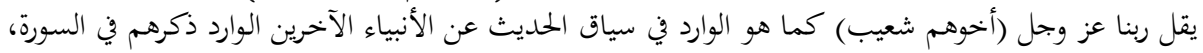

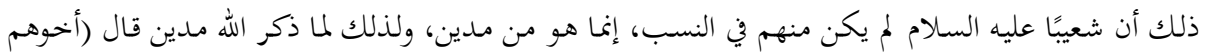




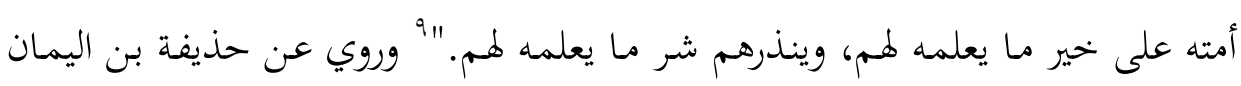

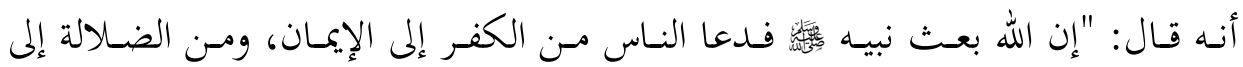
الهدى، فاستجاب من استجاب، فحيّ من الحق ماكان ميتًا، ومات من الباطل ماكان حيًا، ثم ذهبت النبوة، فكانت الخلافة على منهاج النبوة." ·' ولا شكّ في أن هناك تناسقًا واضحًا في ربط السعادة بالعبادة، ولا بدّ من أن تكون هذه العبادة صحيحة، غايتها سامية، بالتوجهه إلى الله سبحانه، ولو كانتت العبادة لغيره لكان التردي إلى أسفل سافلين. إن الرسالة السماوية تسمو بالإنسان وتوقظ فيه حس

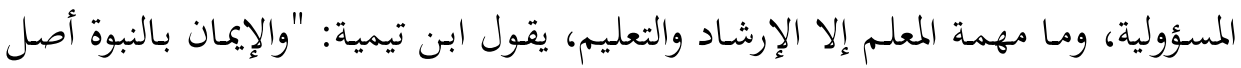
النجاة والسعادة، فمن لم يمقق هذا الباب اضطرب عليه باب الهدى والضلال، والإيمان والكفر، ولم يميز بين الخطأ والصواب." ويقـول صـاحب المنـار : "إن موضـوع الرسـالة تعليم وإرشـاد إلهي يملـك الوجــدان،

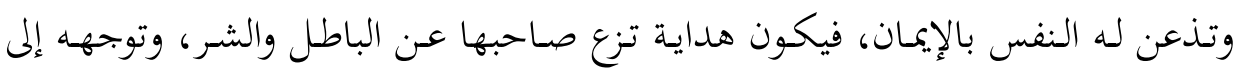

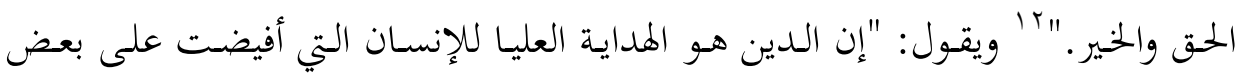

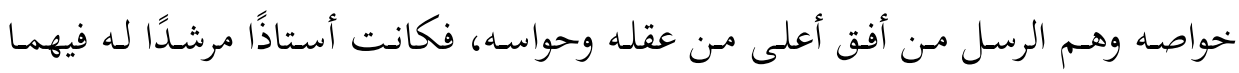
لكيلا يستعملهما فيما يضـره في سيرته الشخصية والاجتماعية، وهاديًا له إلى السعادة

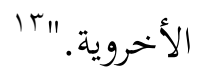

والحقيقة أن هذه المسألة واضحة في وصف الأنبياء عليهم الصلاة والسلام، ومنهم

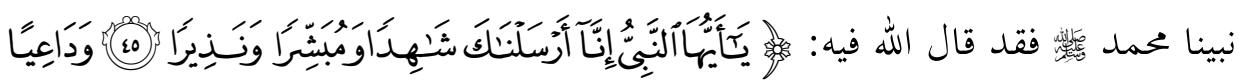

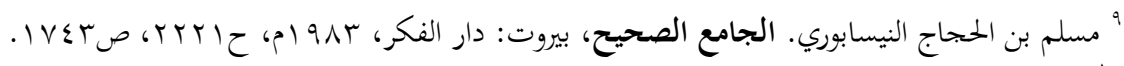

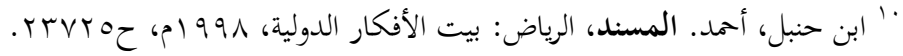

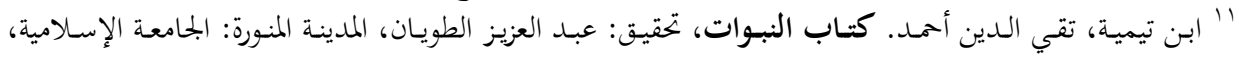

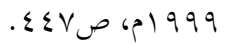
r' عبده، محمد، ورضا، محمد رشيد. تفسير القرآن الحكيم، المشهور بتفسير المنار، بيروت: دار المعرفة، طץ،

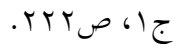

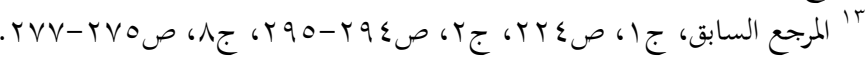




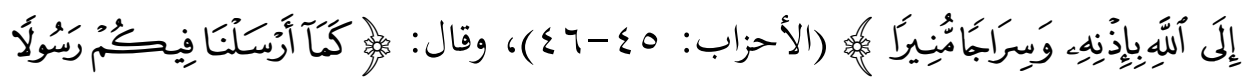

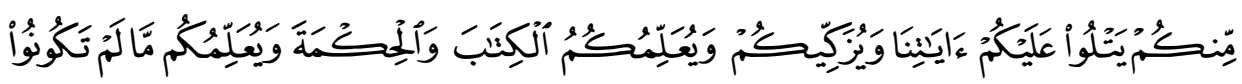

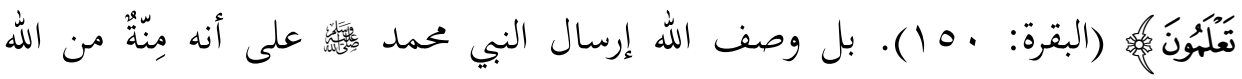

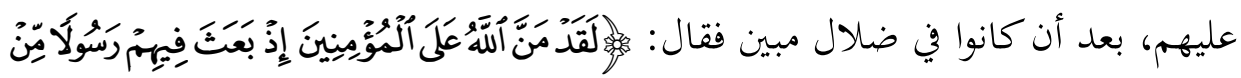

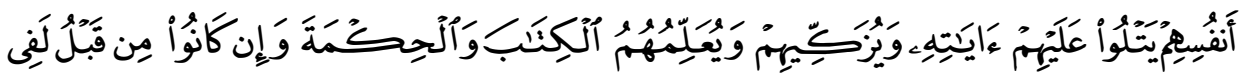

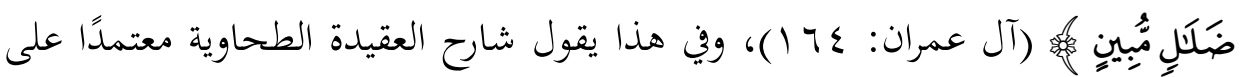

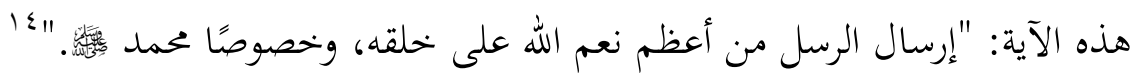

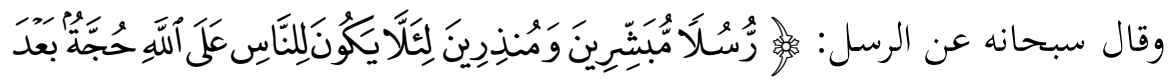

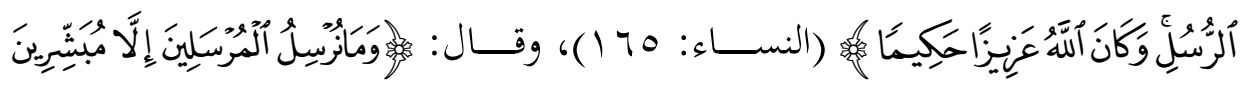

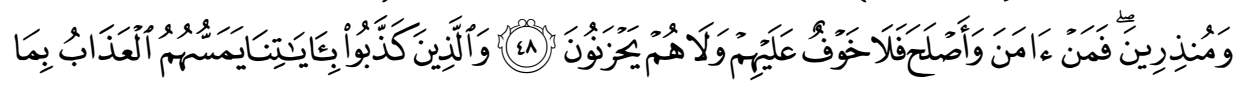

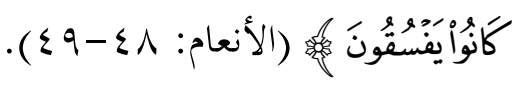

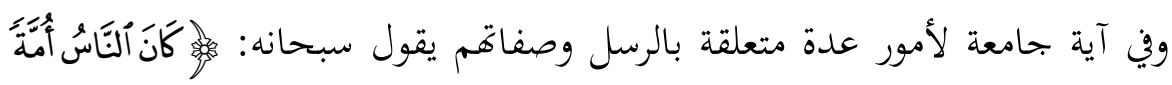

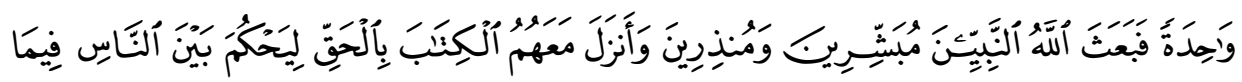

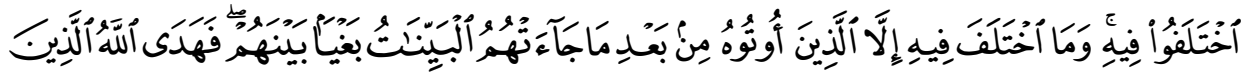

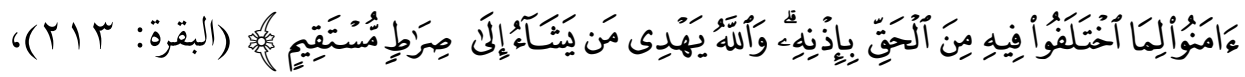

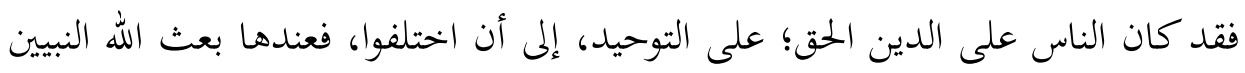

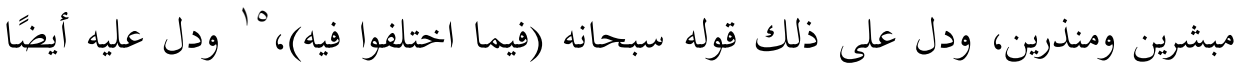

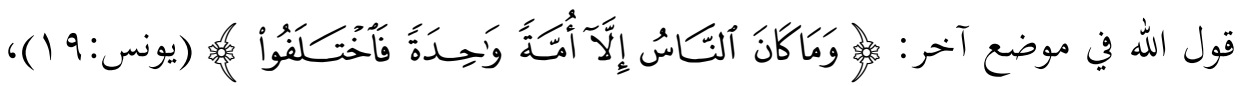

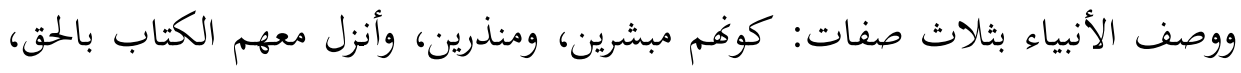

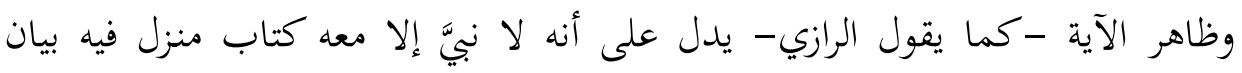

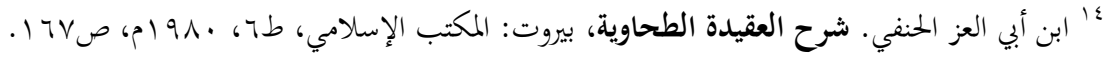

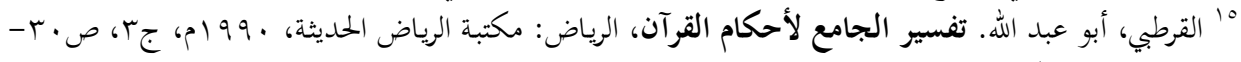

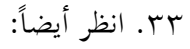
- الرازي، الفخر, . التفسير الكبير (مفاتيح الغيب)، بيروت: دار إحياء التراث، طج، 999 1م، جه، ص11. 


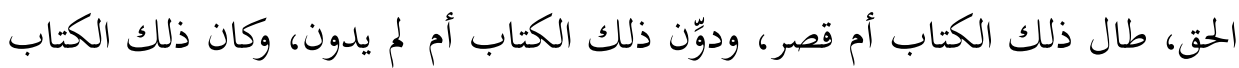

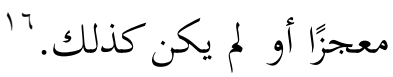

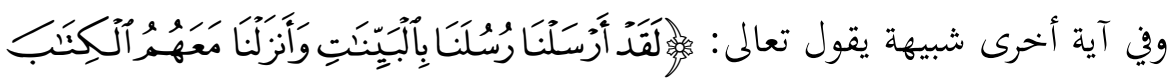

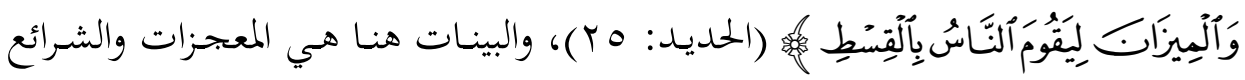

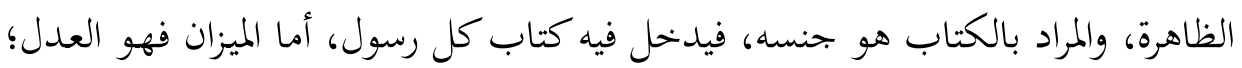
أي أمرهم الله بالعدل حين بيَّن أسبابه وموجباته.

وقد وصف الله الرسالات والكتب بأها نور وهدى، فالنبوة هي وسيلة تبليغ هذا

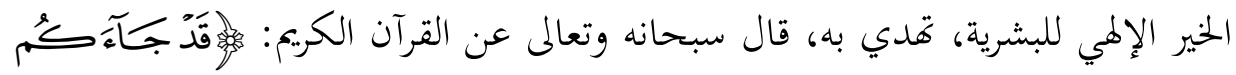

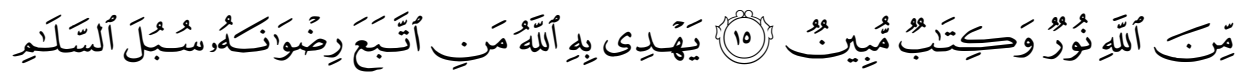

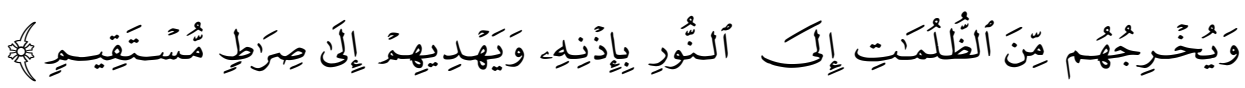
(المائدة: 10 -7 (1)، وقل مثل ذلك في الكي الكتب المنزلة على سائر الأنبياء عليهم الصلاة

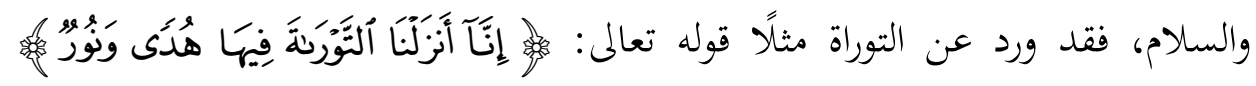

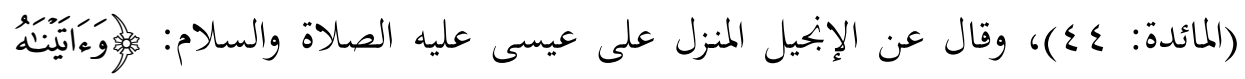

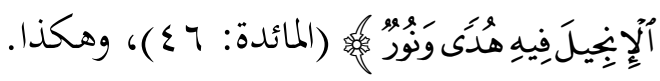
ومن أسماء هذه الكتب وأوصافها ندرك -عملياً وبوضوح- أن الأنبياء هم المرشدون

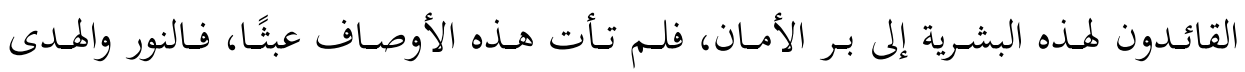

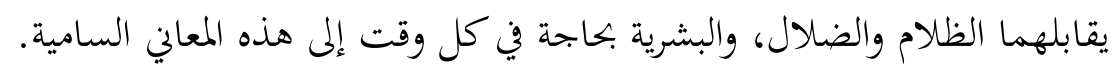
وقد شبه الرسول

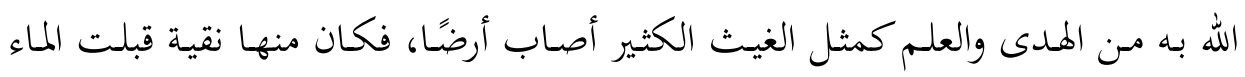

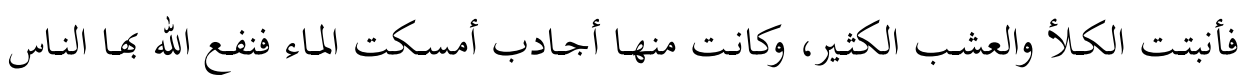

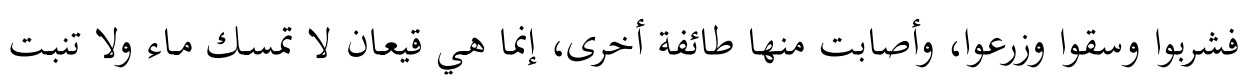

$$
\begin{aligned}
& \text { "1 الرازي. التفسير الكبير (مفاتيح الغيب)، مرجع سابق، جه، صع أ-10. }
\end{aligned}
$$

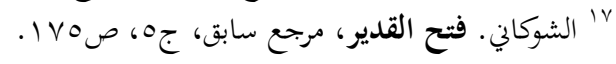




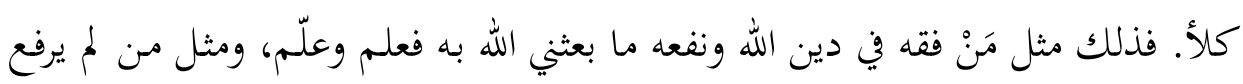

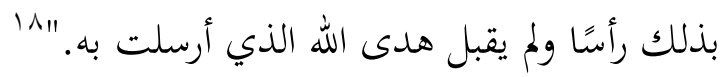

ولا شكّ في أن العلماء قد ركزوا في كلامهم على موضوع العبادة كثمرة لهذا الإرشاد

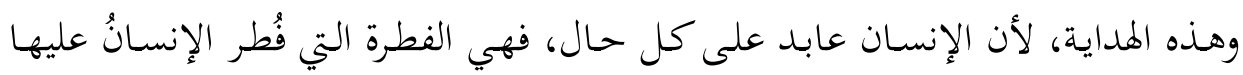

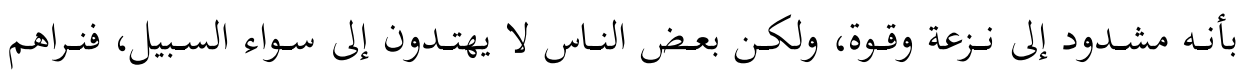

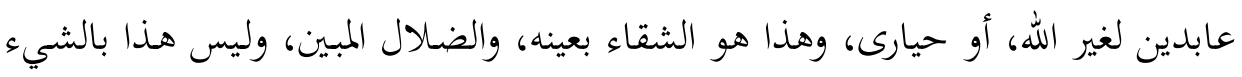

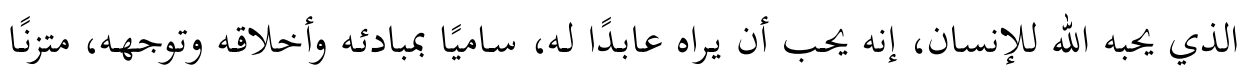

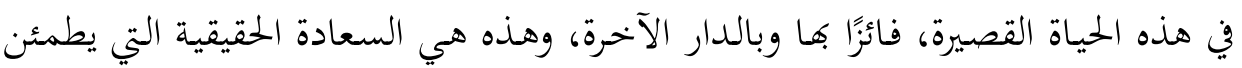

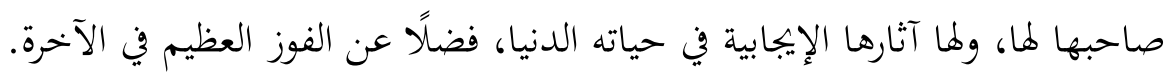
ولو ترك الناس من دون بيان وإرشاد وأوكلوا لأنفسهم، لظلوا في الضلالات بسبب

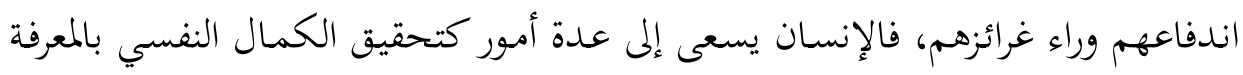

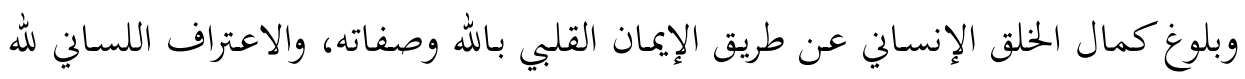

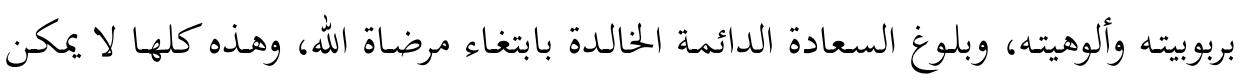
تحقيقها إلا عن طريق نبي مرشد. 19

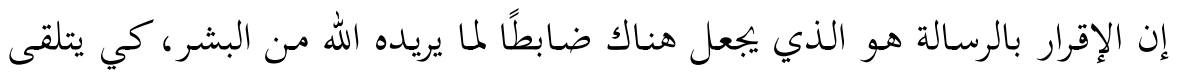

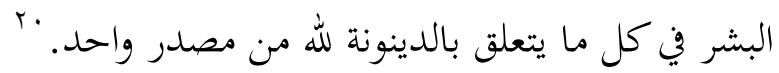
وثمـة مسألة أخهرى مرتبطـة بالإرشـاد، إفـا التربية النبويـة التي تؤهل الأتبـاع لقيـادة

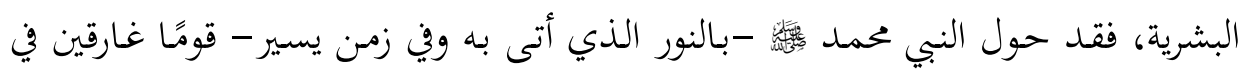

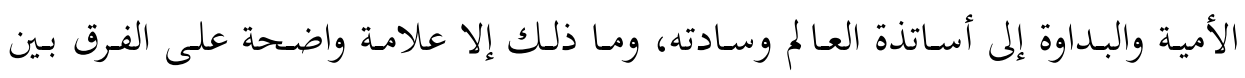

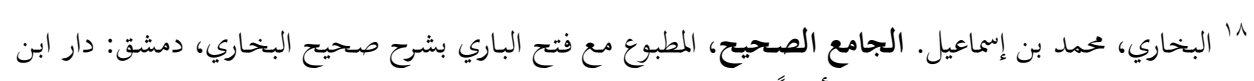

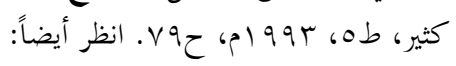

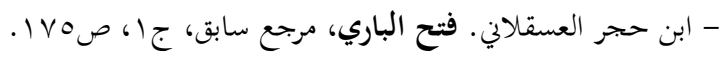

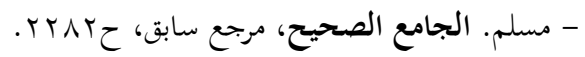

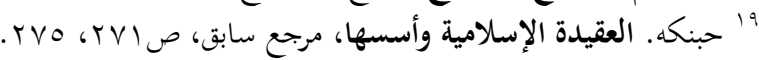

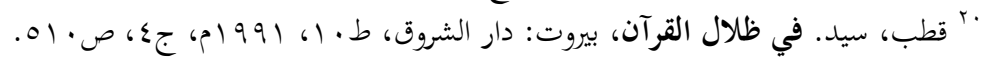


منهجي التلقي؛ منهج الله ومناهج العبيد، فمنهج الله، حياة وارتقاء وانقلاب إلى الأفضل والأسمى، وهيهات أن تبلغه مناهج العبيد.

\section{r. النبوة سبيل تأكيد المعجزات الربانية واستمرار المعجزة القرآنية:}

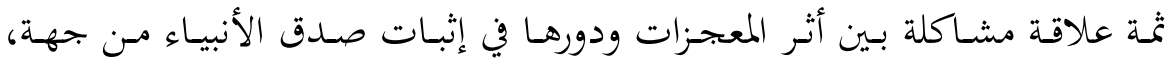
وحاجة الأنبياء إلى هذه المعجزات الدالة على صدقهم من جهة أخرى، وقد أفرزت هذه

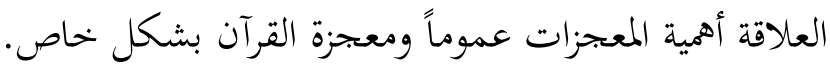

لا شكَّ في أن هناك ِِكَماً كثيرة وراء المعجزات التي أيد الله هـا رسله، وهي أمور

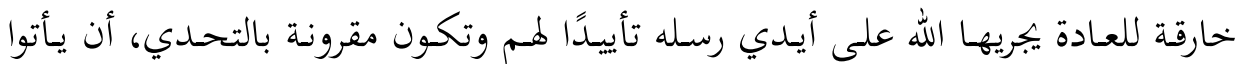

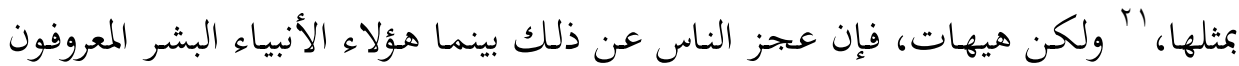

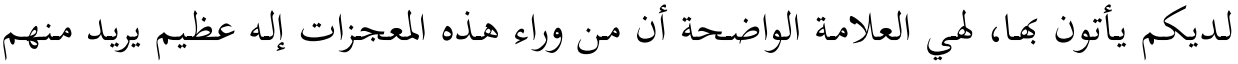

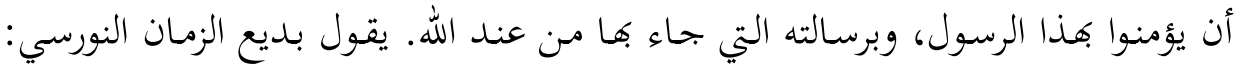

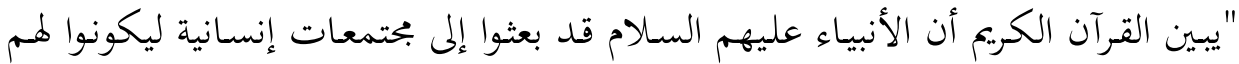

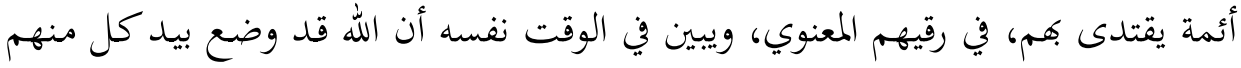

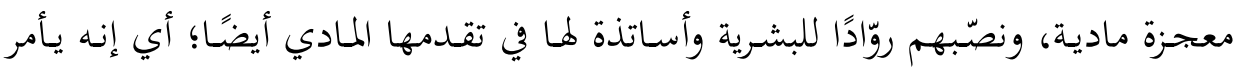

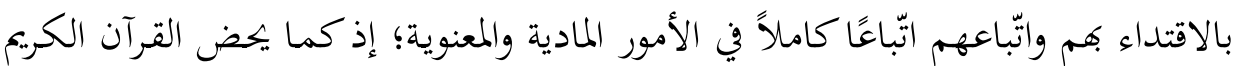

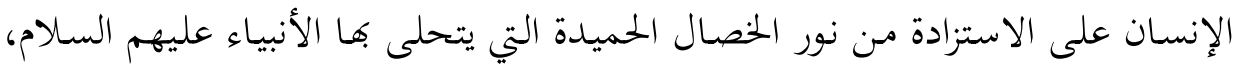

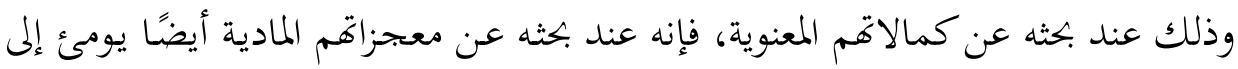

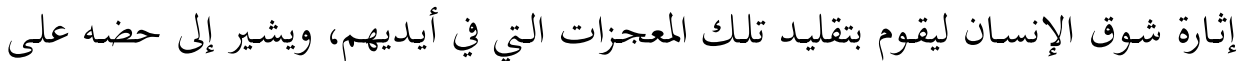

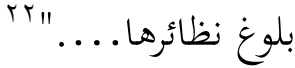

والنورسي هنا يتحـدث عن العوامل النفسية المصاحبة للإنسـان في حـال أن تكون

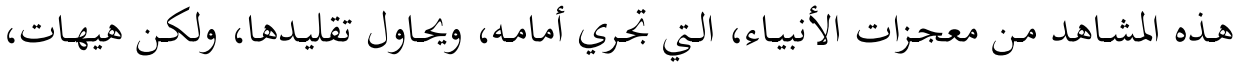

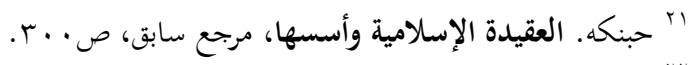

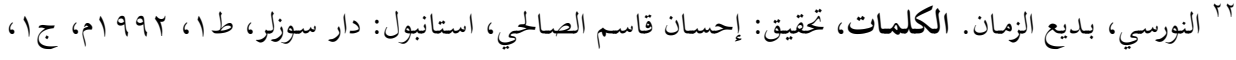




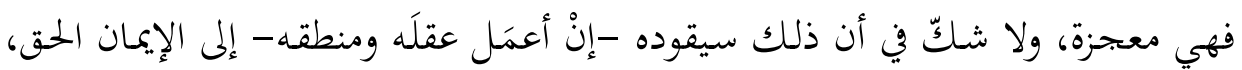

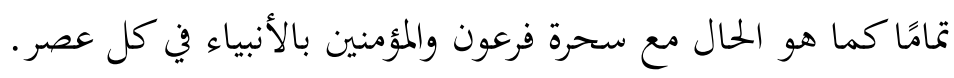
بنحـد أن مـن المهـم هنـا الإشـارة إلى أن للمعجزة دورًا مهمًا في تأييد الأنبياء في أداء

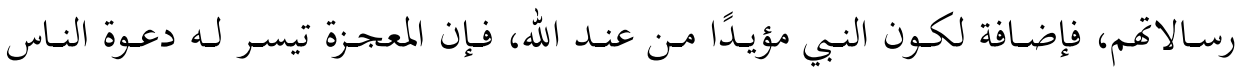

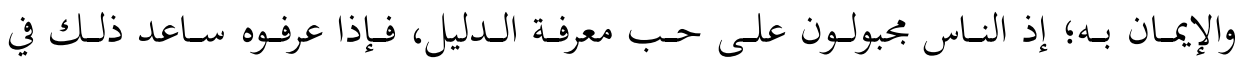

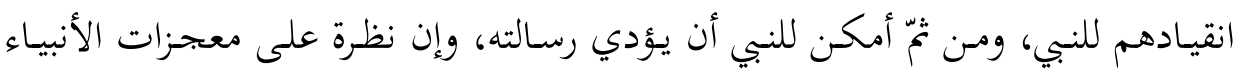

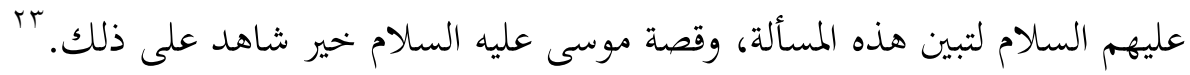
وثمة نقطة أخرى أشار إليها الميداني، وهي أن كثيرًا من الحقائق العلمية التي لا غنية

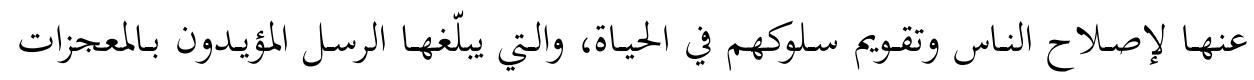

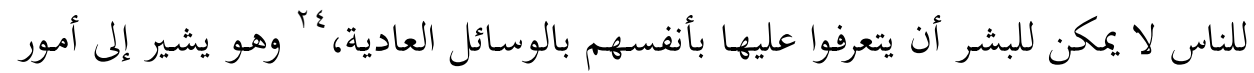

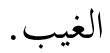

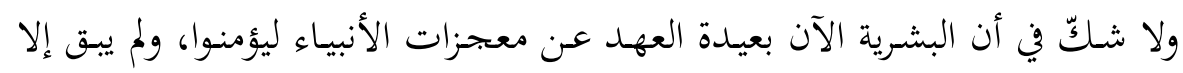

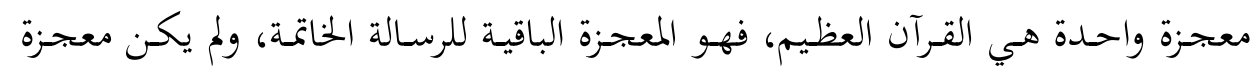

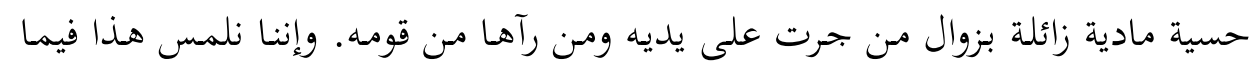
قاله هُ

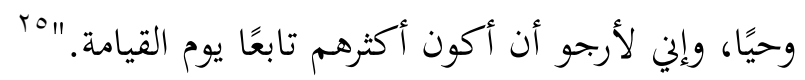

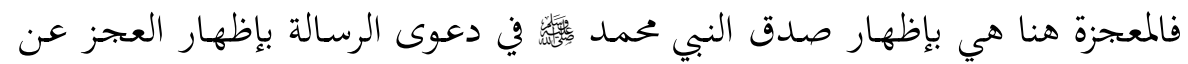

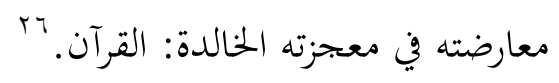

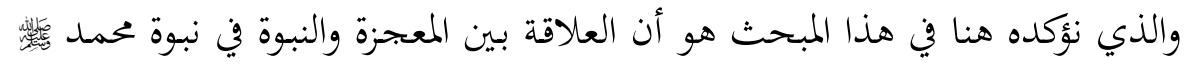

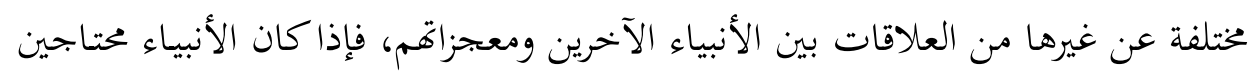

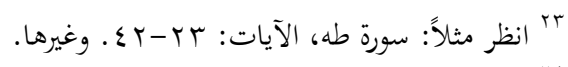

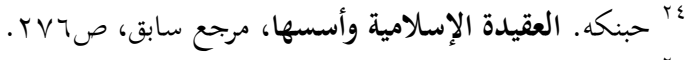

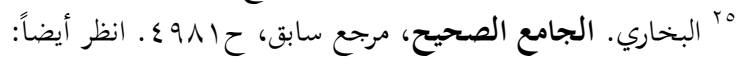

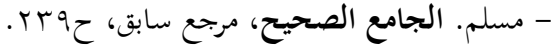

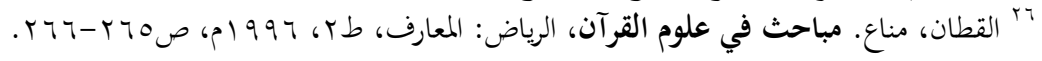




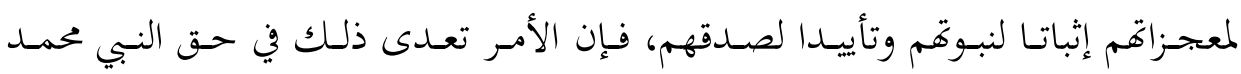

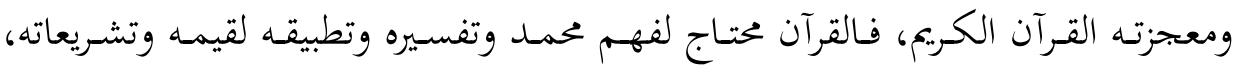

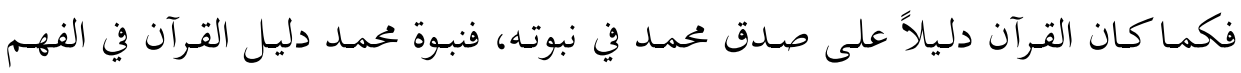

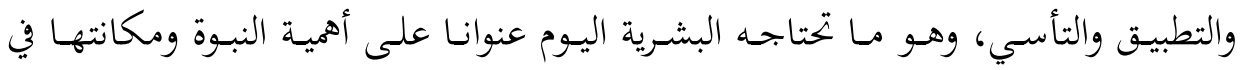

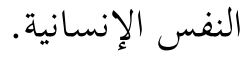

\section{r. النبوة طريق لترشيد الفلسفة والعقل والهوى:}

يقول النورسي: "في تاريخ البشرية منذ القـدم تيـاران عظيمان وسلسـلتان للأفكار

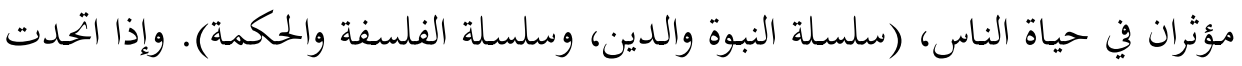

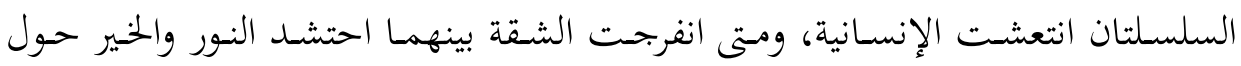
سلسلة النبوة والدين، وبتمع الشر والضلال حول سلسلة الفلسفة.

ولا بـدّ هنا مـن أن نقرر أهمية النبوة التي هي وسيلة لنشر الدين في ضبط مفاهيم

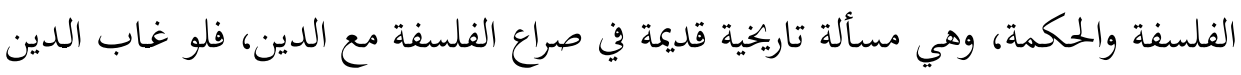

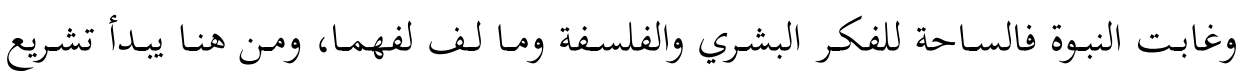

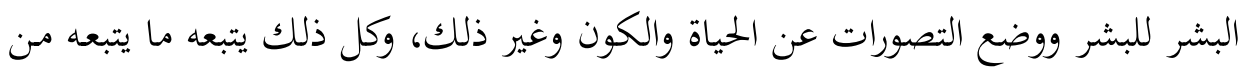
نتائج في الغالب هي سلبية.

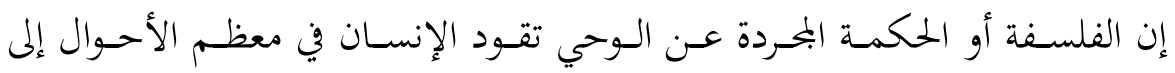

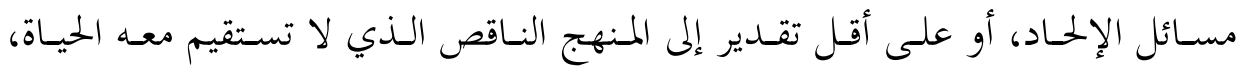

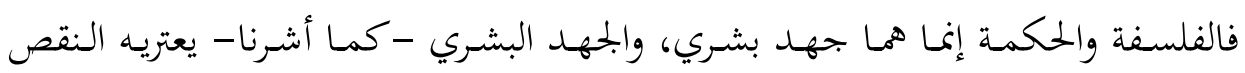

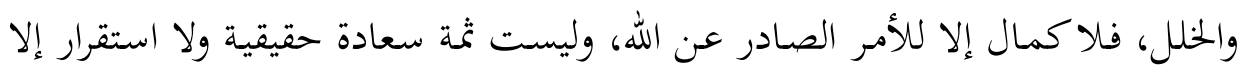

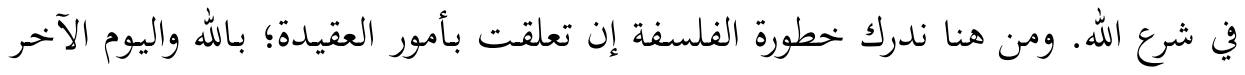

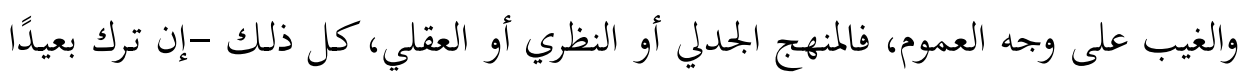

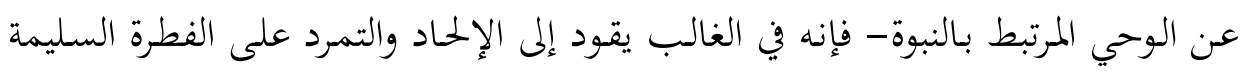
التي فطر الله الإنسان عليها.

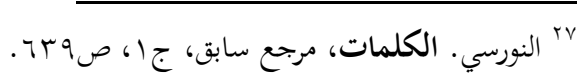




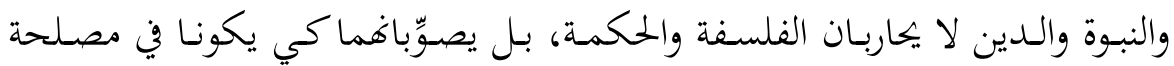

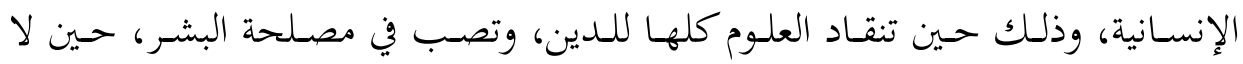

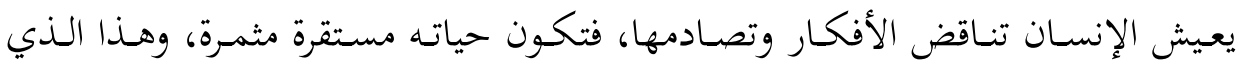
يدعو إليه الدين والنبوة.

إنه لا يمكن للفلسفة وحدها أن تعطينا المفاهيم عن كل ما حولنا، فثمة فرق بين

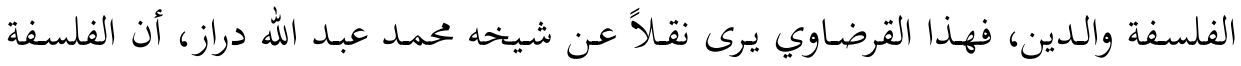

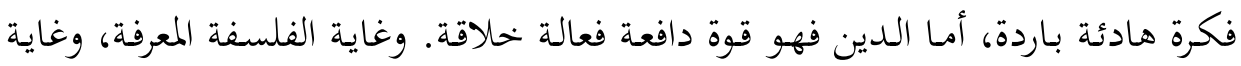

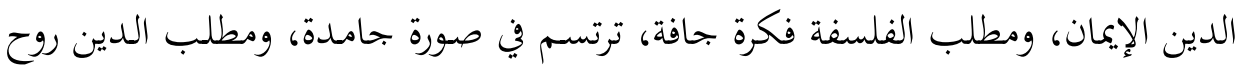

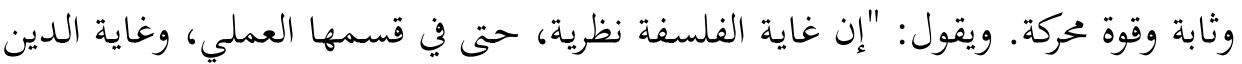

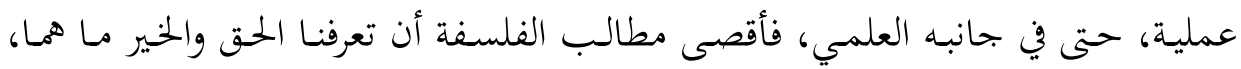

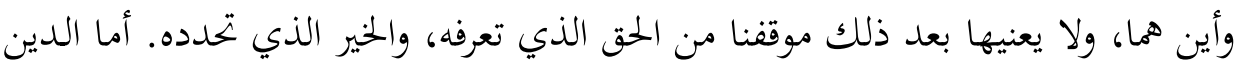

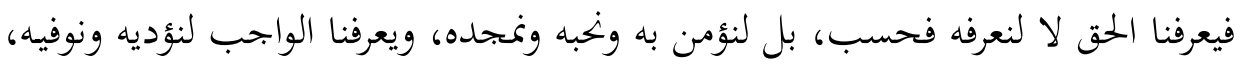

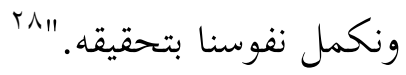

ولعل نظرة تاريخية إلى صراع الفلسفة والدين تتؤكد كيف عاش الناس في حيرة من

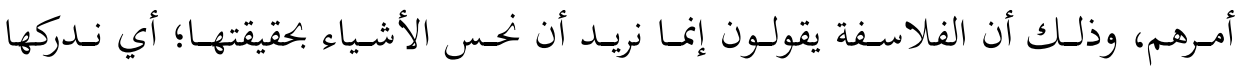

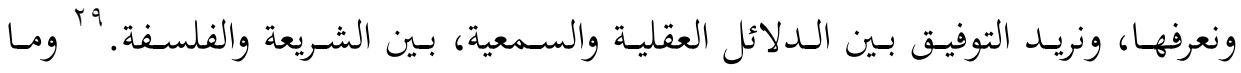

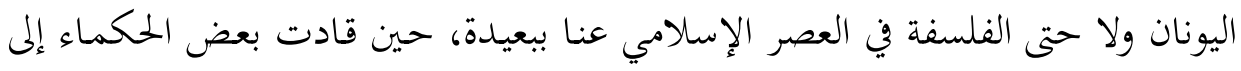
الإلحاد بوضعهم تصورات بعيدة عن الأدلة السمعية واقتصروا فيها على الأدلة العقلية. أما إذا جئنا إلى هداية القرآن ومقاصده، فإننا نرى الفرق بين الوحي والهوى، بل نرى

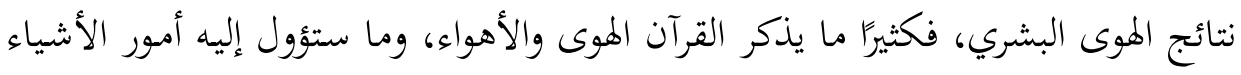

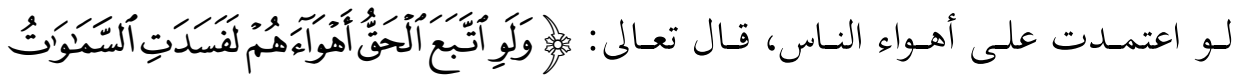
^^^ القرضاوي، يوسف. مدخل لمعرفة الإسلام: مقوماته، خصائصه، أهدافه، مصادره، القاهرة: مكتبة وهبة، طا،

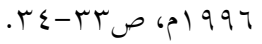

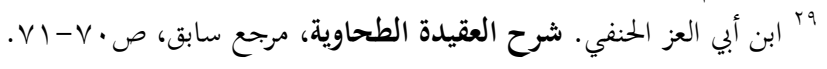




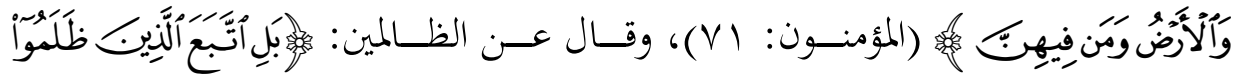

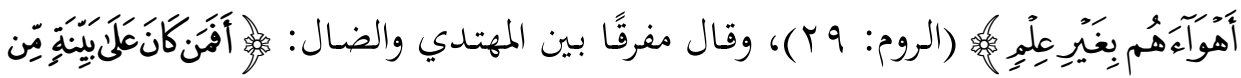

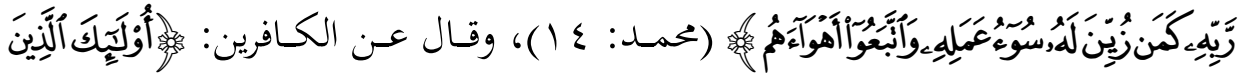

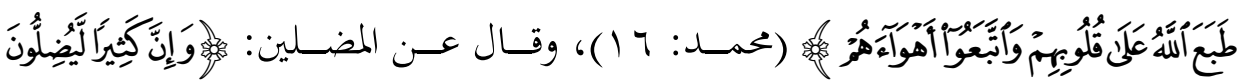

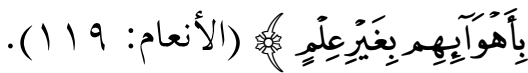

وما أبشع ما صنع بنو إسرائيل حين حكّموا أهواءهم في أنبيائهم، فقتلوا وكذبوا وفقًا

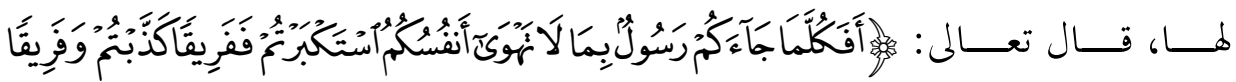

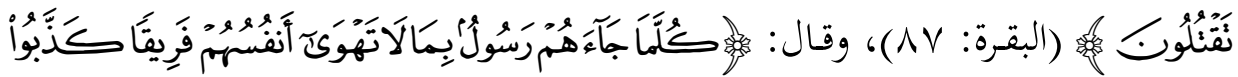

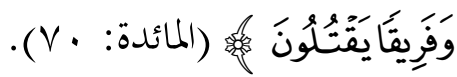

ونودّ هنا نقل شيء من كلام لابن خلدون يعرّف من خلاله هذا المنحى في التفكير

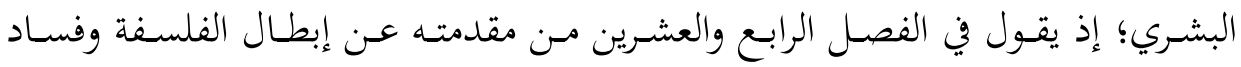

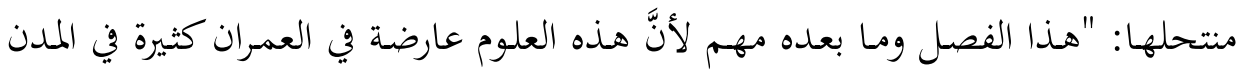

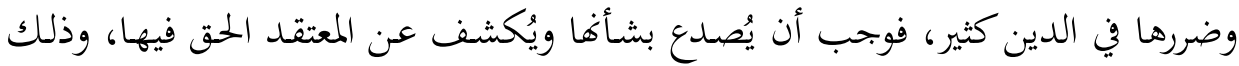

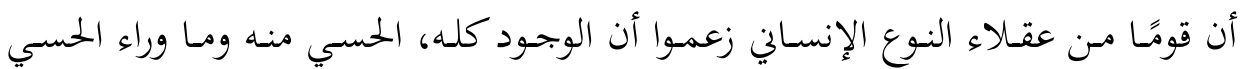

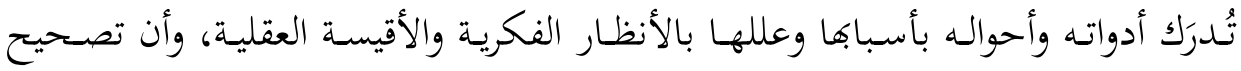

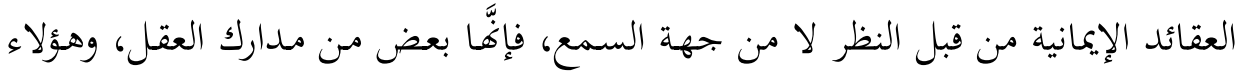

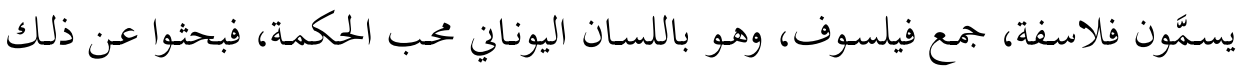

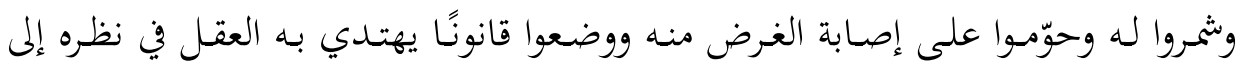

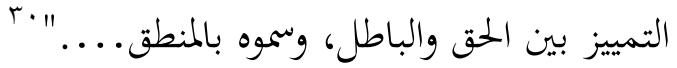

وإذا تحدثنا عن جانب العقل، فكثير من الناس في أيامنا هذه يتحدثون عن إمكانية

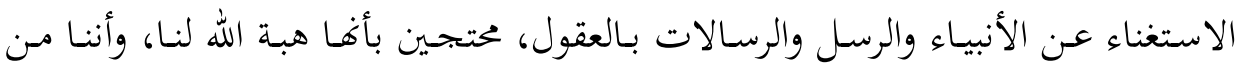

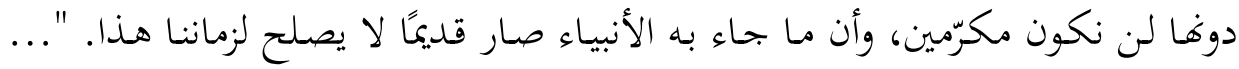




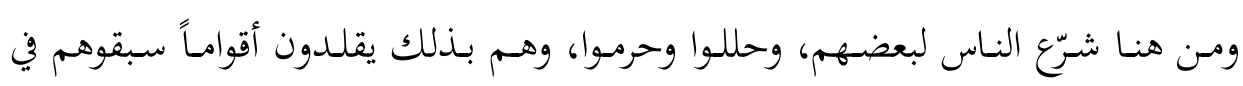

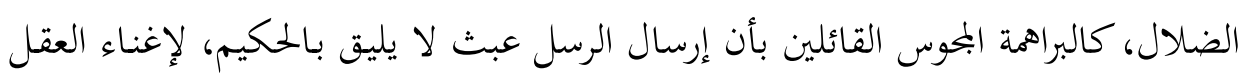

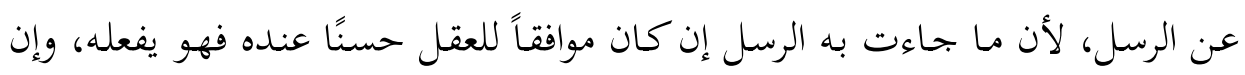

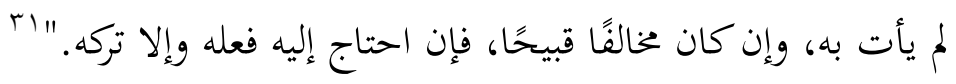

وعلى النقيض من هؤلاء بحد مـن يعترف بوجود العقل ولكنه ينكر معارفه العقلية

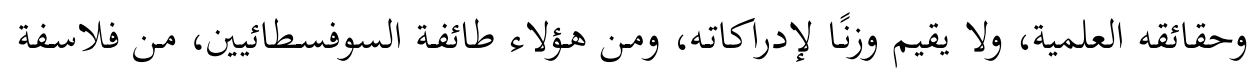

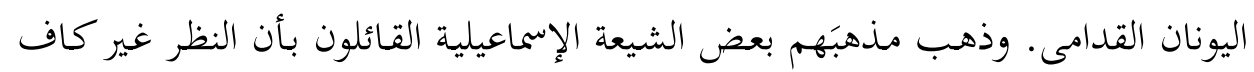

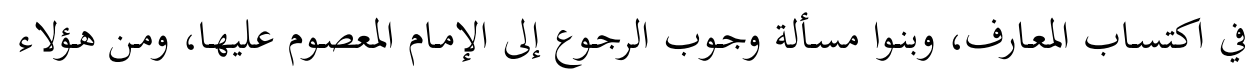

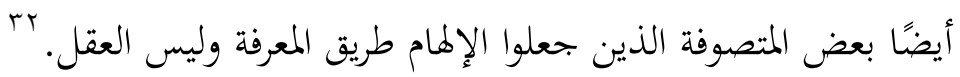

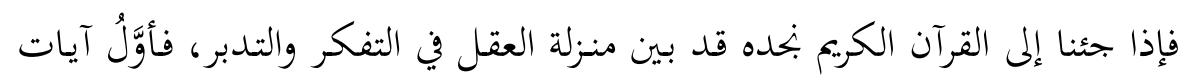

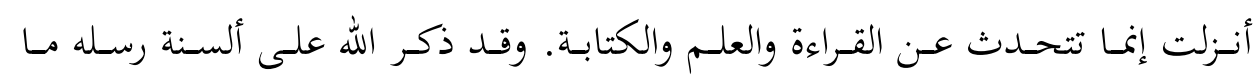

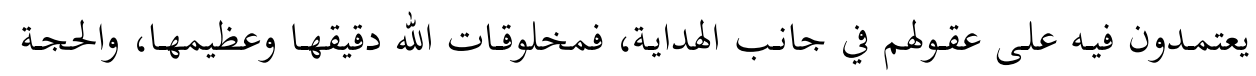
الدامغة فيما كان بينهم من نقاش في الله تعالى. لقـد اعتنى القرآن عناية واضحة بضرورة استخدام الإنسان لعقله، ولحواسه، ودعاه

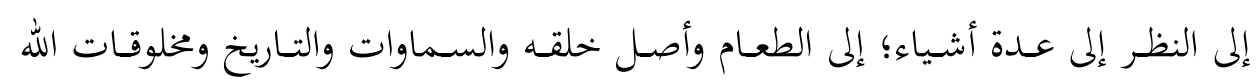

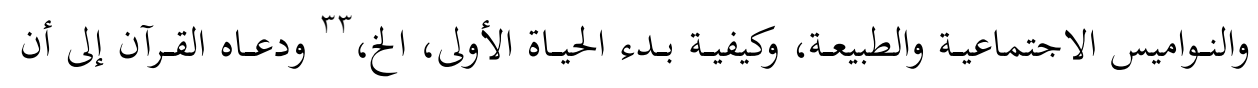

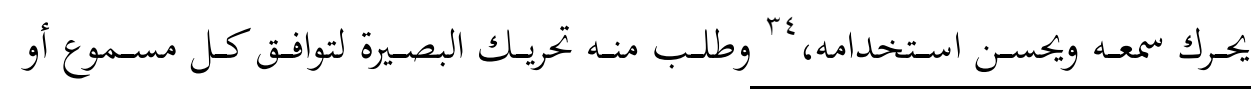

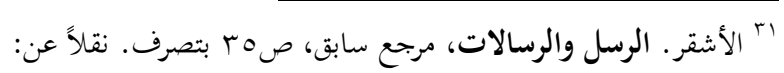

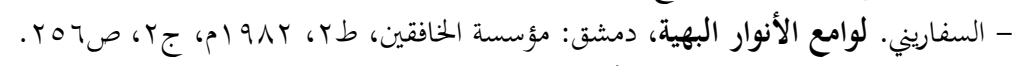

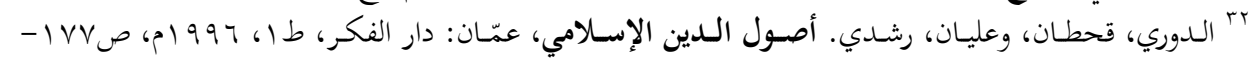

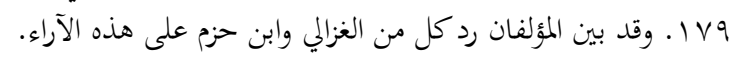

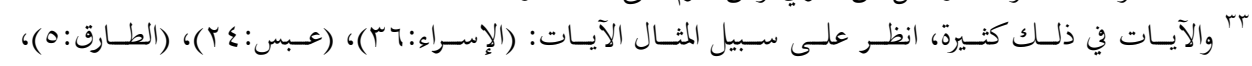

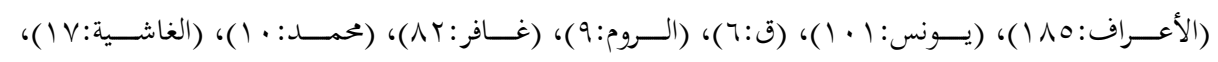

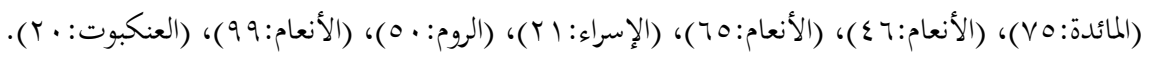

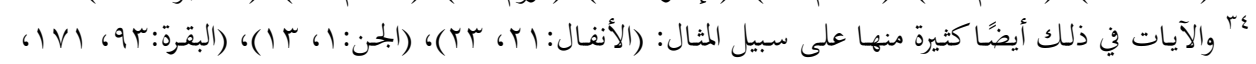

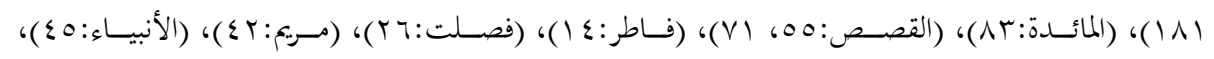




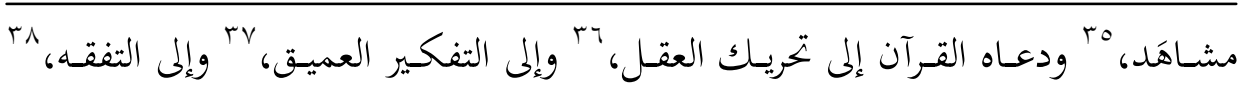

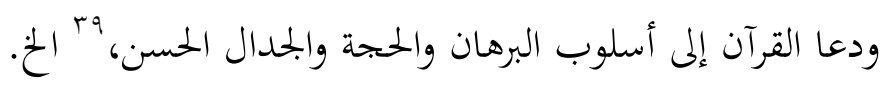
وفي هذا المحال أيضًا ما يمكن أن يكون اجتهاد العقل في فهم بعض نصوص الشرع مما لم يكن قطعي الدلالة، فللعقل إبداعاته في الاستباط والفهم. وجانب آخر وميدان فسيح للعقل هو الإبداع في أمور الحياة، وهذا لا يعارضه الدين بل يطلبه، وهو مما يندرج في إعمار الأرض وضرورة الارتقاء البشري في حياته.

وون هنـا ندرك بطلان مـا ذكره بعض النـاس مـن ضرورة استغناء العقل عن الوحي

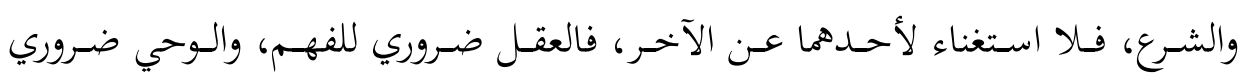
للضبط. وبكما يعيش الإنسان في السعادة المأمولة، وهذه هي دعوة الأنبياء والرسل عليهم الصالاة والسلام كما بينها القرآن.

ولعل الأمثلة على ذلك كثيرة، نأخذا منها على سبيل المثال قصة إبراهيم مع أبيه

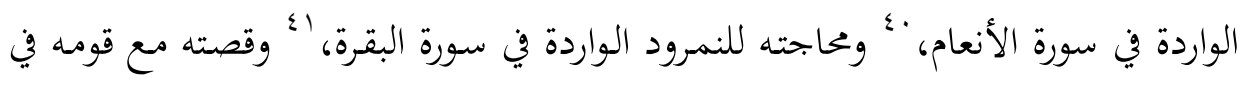
تحطيم التماثيل وبطلان أن تكون آلهة، وقد وردت في سورة الأنبياء. rع ومثال آخر هو قصـة ذلك المؤمن مـن آل فرعـون وقـد كتم إيمانه، وكيـف اعتمـد على المنـاظرة والنقـاش

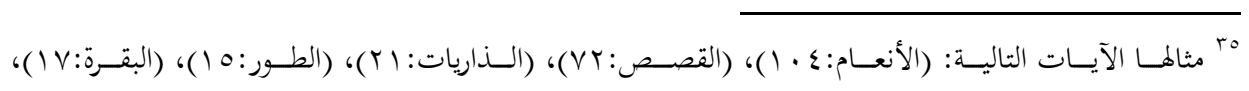

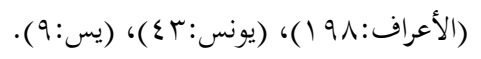

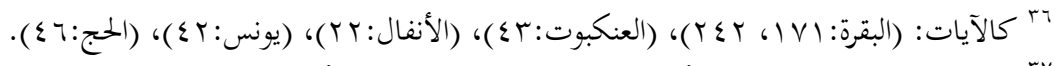

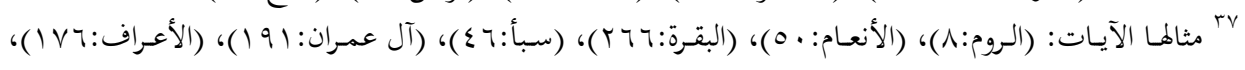

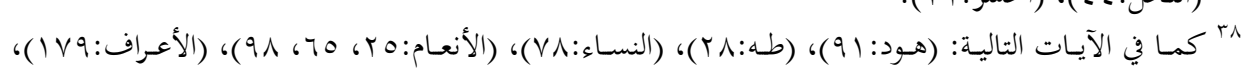

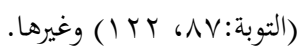

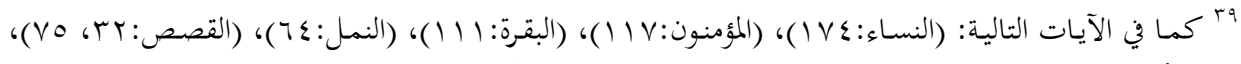

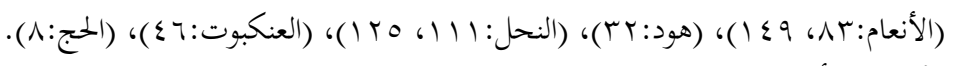

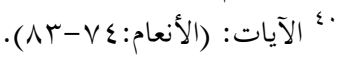

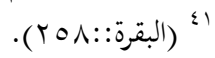

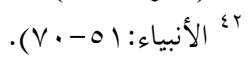


المنطقي من أجل نصرة الحق، بـ وهكذا في جوانب مختلفة من قصص بعض النبيين في

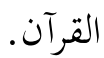

إن النظرة الصحيحة للعقل هي أنه محتاج في قيادة القوى الإدراكية البدنية إلى ما هو خهير له في الحيـاتين: الـدنيا والآخـرة، وإلى مُعـين يستعين بـه في أمسور الإيمان وبيـان الخهير والنفع والضـر، وتحصيل وسـائل السعادة، وهـا المعـين يجـب أن يكون من جنس البشر،

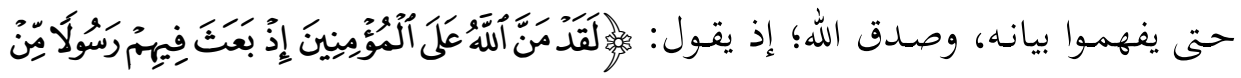

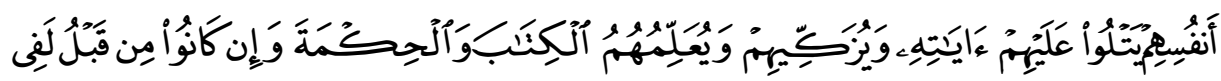

$$
\text { ضَكَلَّ مُبِينِ }
$$

إن العلم وححده لا يكفي في إسعاد البشرية وتنظيم أمورها، فهو مـا زال عـاجزًا عن

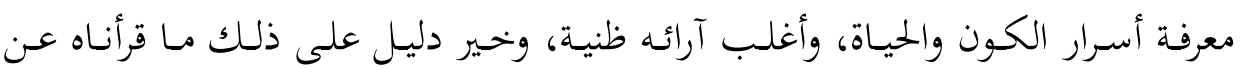
نظريات علمية أريد لها أن تسود، ولكن سرعان ما ثبت بطلانها أو على الأقل نقصها،

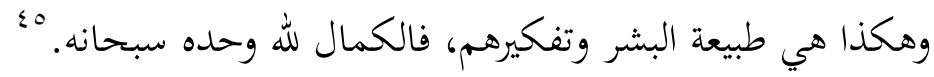

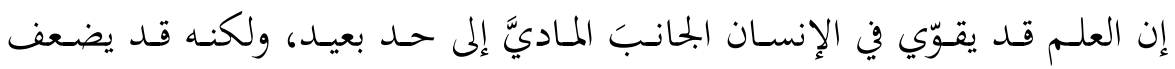

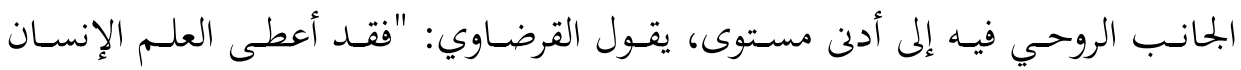

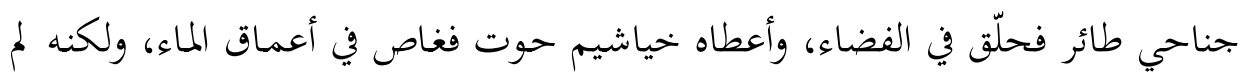
يعطه قلب إنسان. وحين يعيش الإنسان في الحياة بغير (قلب الإنسان) تستحيل أدوات

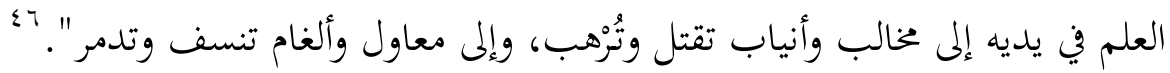
وقد بيّن بجموعة مـن العلمـاء الغربيين ضرورة حاجـة البشرية إلى مـا هو زيـادة على العلم، فـالعلم قاصر عن إدراك مـا وراء الطبيعة، بـل مـا يجلـب السعادة الحقيقيـة للبشر .

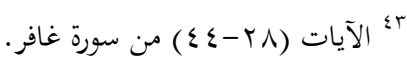

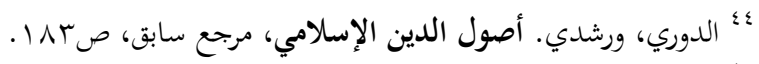

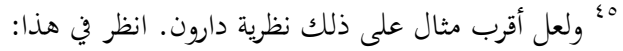

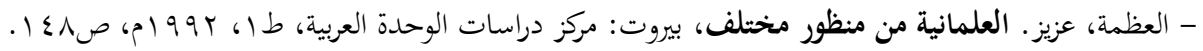

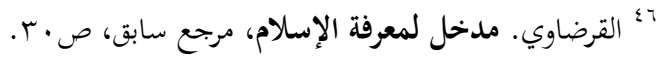


يقول بول كلارنس: "... وعندما تزايد علمي ومعرفتي بالأشياء، من الذرة إلى الأجرام

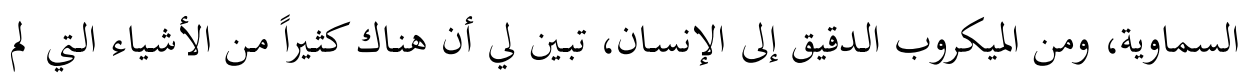

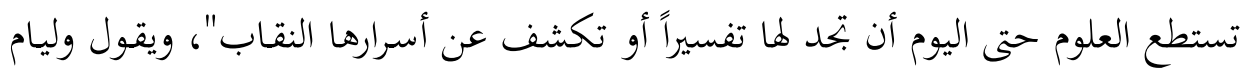

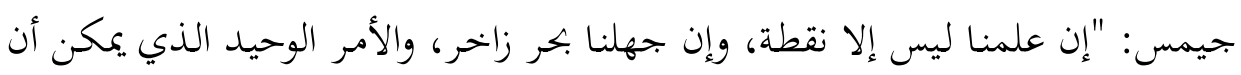

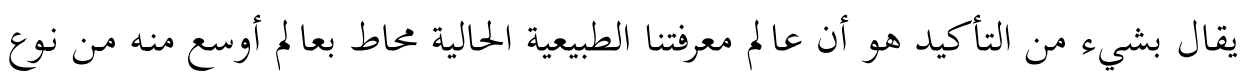

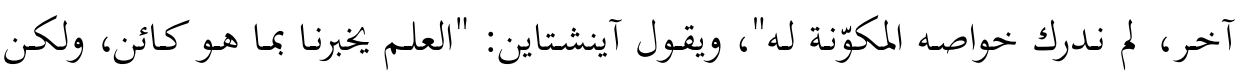

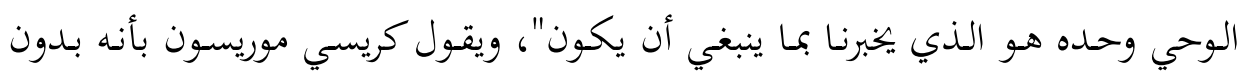

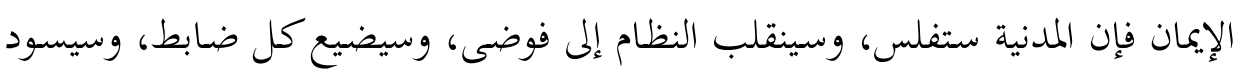
الشر العالم.

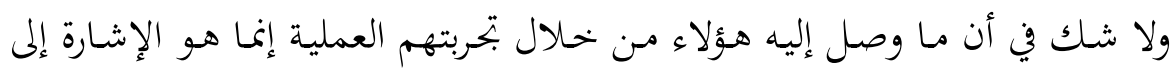

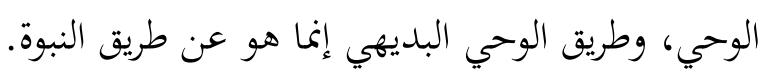

\section{ع. النبوة تأكيد لخطاب النفس الأخلاقي وتحفيز لها وتعزيز وتهذيب:}

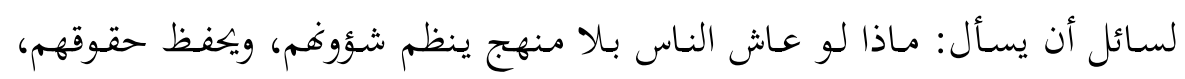

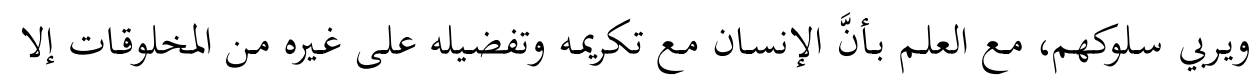

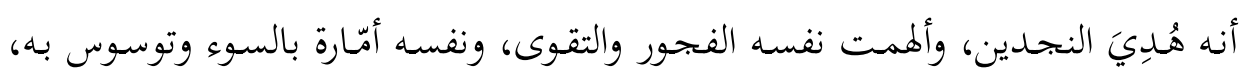

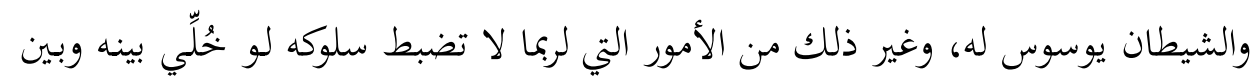

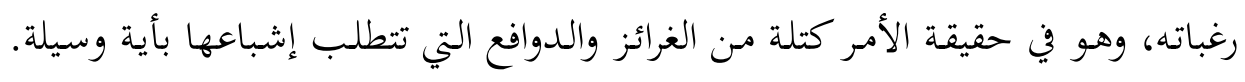

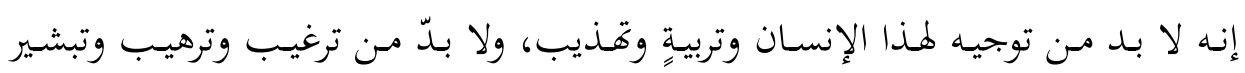

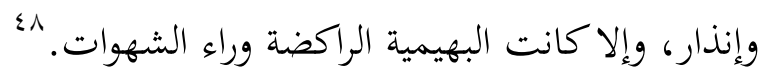

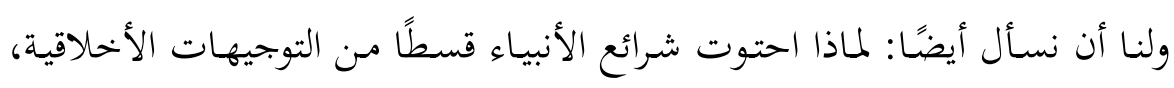

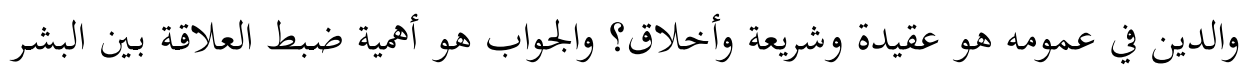

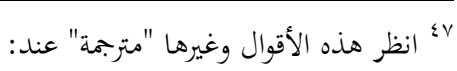

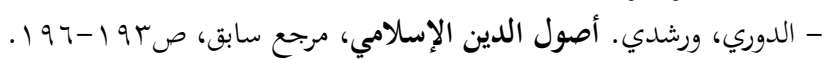

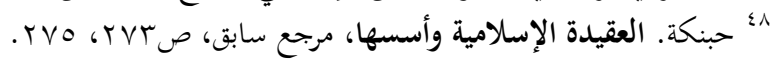




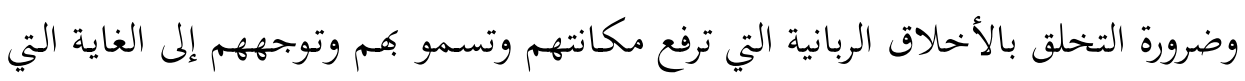

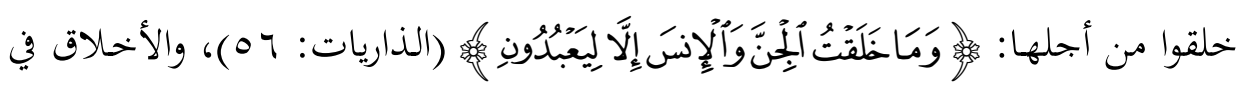

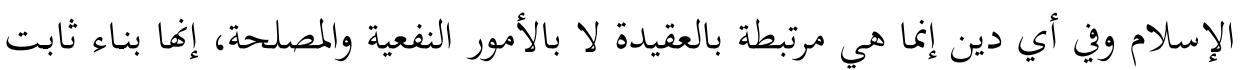
متين تماماً كالعقيدة. ويشير العلماء إلى مثل هذه المعاني، فيقول النورسي مثلاً: "... بينما الذين هـم في النيا

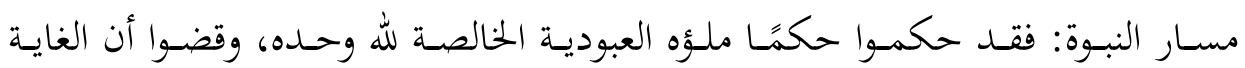

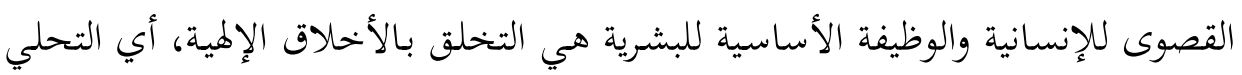

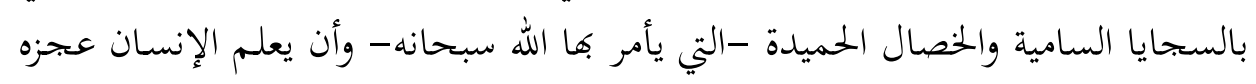

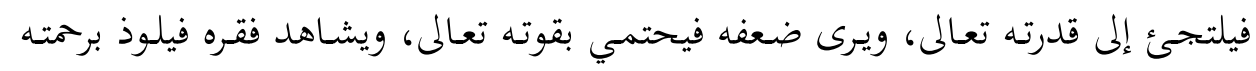

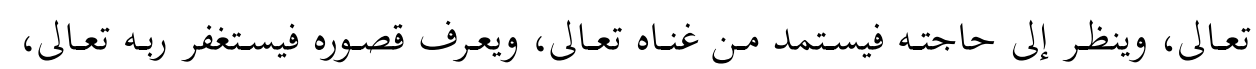

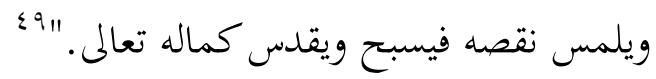

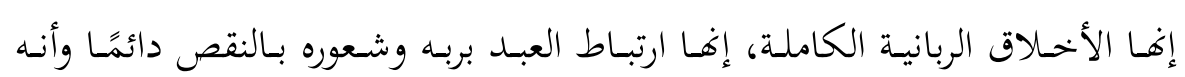

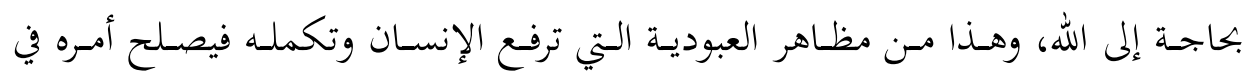

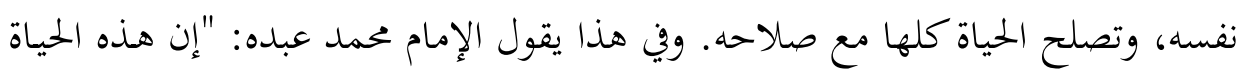

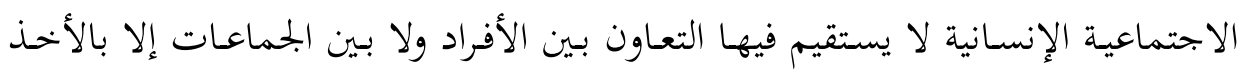

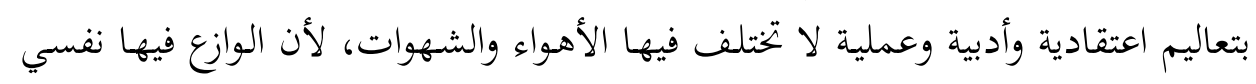

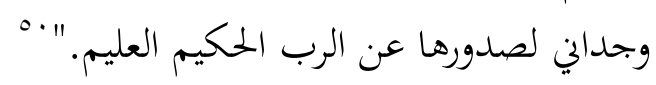

ولا بدّ من أن نعلم بجلاء أن من القواعد المقررة للنبوة في حياة الإنسان الشخصية:

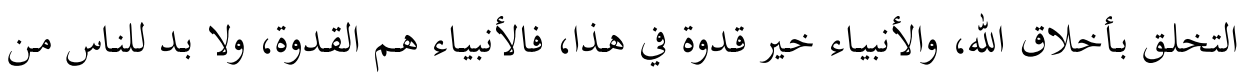

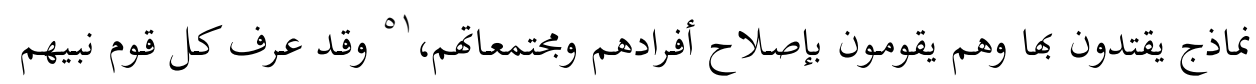

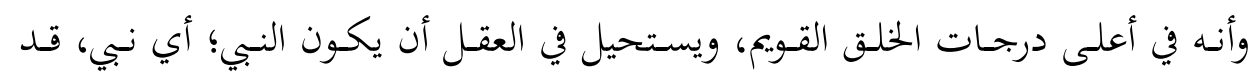

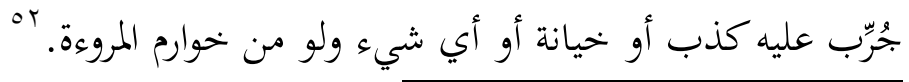

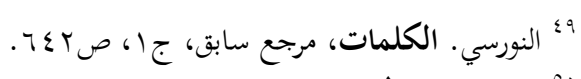

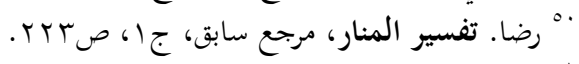

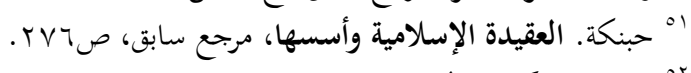

$$
\begin{aligned}
& \text { ro }
\end{aligned}
$$


أمـا مـا يفتريه بعض اليهود والنصارى من إجازة الصفات القبيحة والذنوب العظيمة على الأنبياء، ما هو إلا نتيجة لسوء اعتقادهم فيهم، كيف لا وقد قتلوا الأنبياء بناء على لئ تحكيم أهـوائهم، فقـد زعـم اليهـود أن أبناء يعقوب وسليماءلهان عبدوا الأصنام، وأن هـارون قدم قربانًا للشيطان، وأن موسى صنع تمثال حية من نحاس لشفاء كل لديغ، وأن هارون

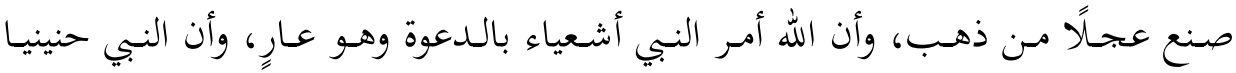
يكذب على الله، وأن الأنبياء كذبوا على بعضهم، وأن الأنبياء أمروا بالقتل والتمثيل، وأن

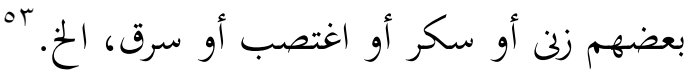

ولا بـدّ مـن أن نذهـب إلى أبعد مـن العلاقة بين البشر أنفسهمه، حين بنعل دستور الأخلاق يعم الناحية الاجتماعية كلها، ومنها دستور التعاون بين سائر المخلوقات، وقد بين ديننا الحنيف أصول التعامل مع الحيوانات حيث الرحمة والإحسان.

وأخسيرًا، مهمَّة تأكيـد خطاب النفس الأخلاقي وتحفيزه وتمذيبه، مهمهة الأنبياء في

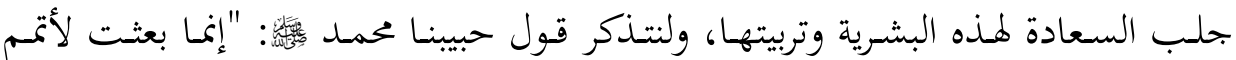

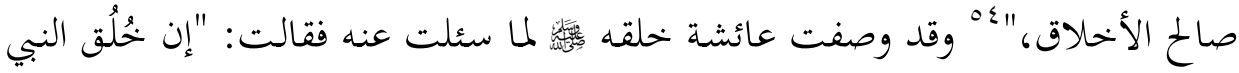

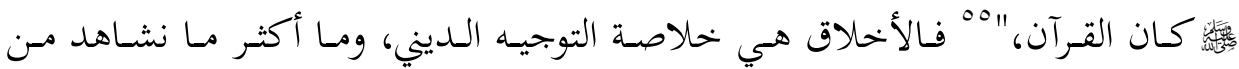
تناقض المواقف في الشخصية المسلمة، حين يكون الإنسان عابدًا قائمًا بواجباته ولكن.

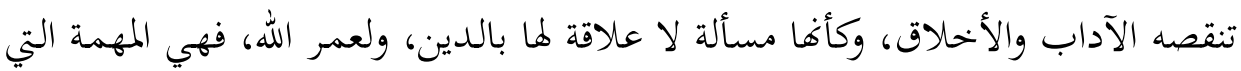
قام بها الأنبياء في أن يكونوا هـم أنفسهم قدوة لغيرهم فيما نسميه الشخصية المتكاملة المتربية على المنهج الشـمولي. وفي ذلك يقول الشيخ محمد قطب: "إن الدين هو المنبع

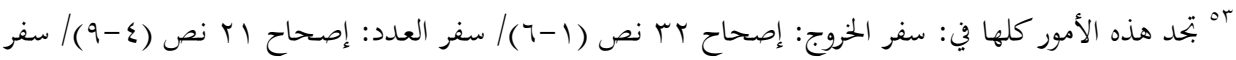

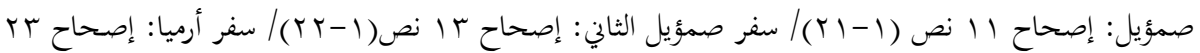

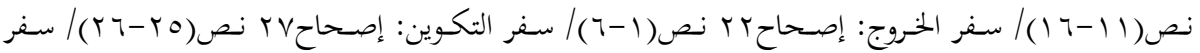

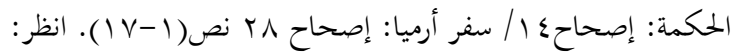

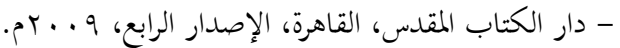

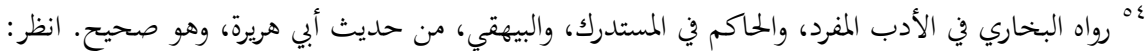

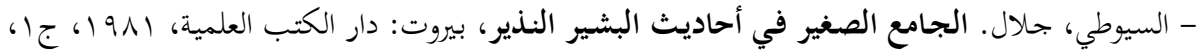




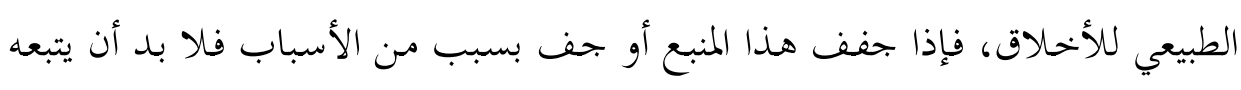

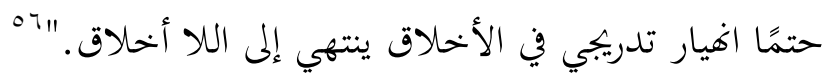

ولا بدّ في هذا السياق من التطرق إلى بعض ما يتصوره دعاة العلمانية من مفاهيم

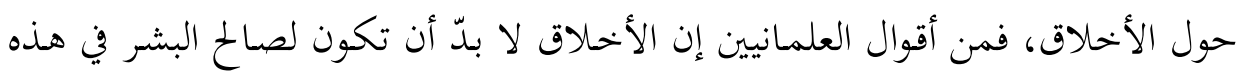

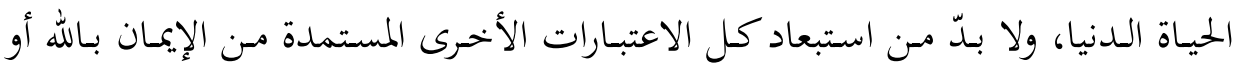

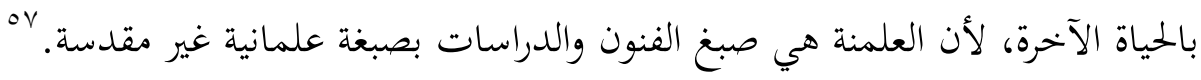
وفي المقابل بند المنصفين من علماء الغرب يقرون بحقيقة الحاجة إلى القيم الدينية،

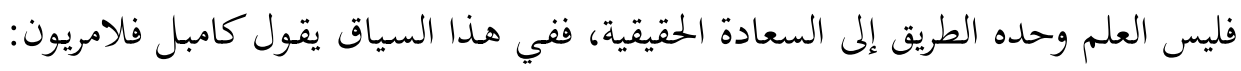

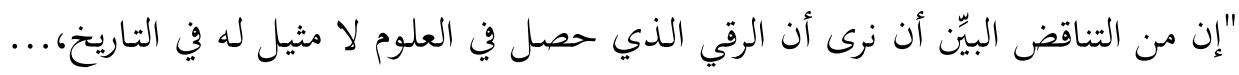

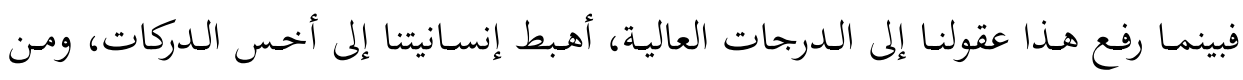

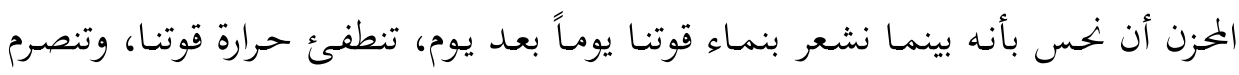

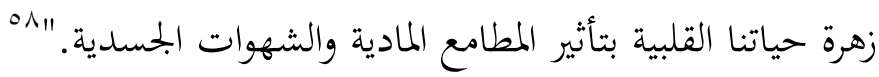

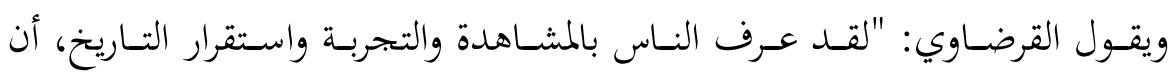

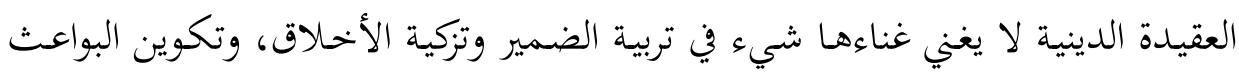

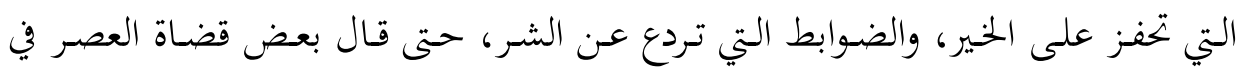

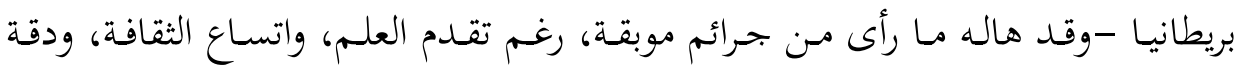

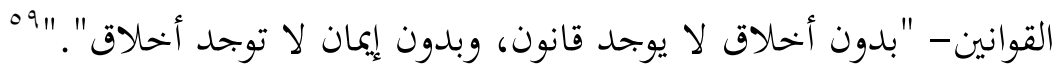
وحين نبتعد عن النبوة والوحي نرى تشريع الناس لبعضهم بعضاً، واجتهادهم في

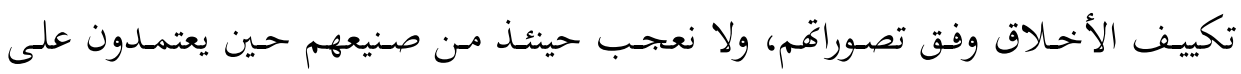

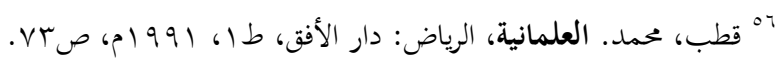

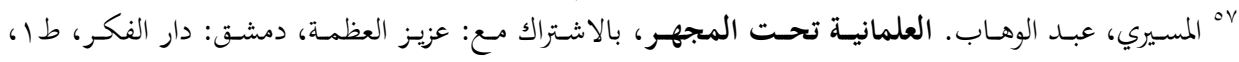

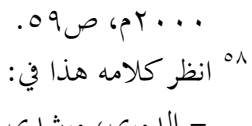

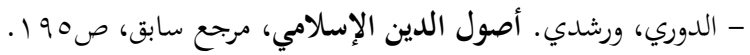

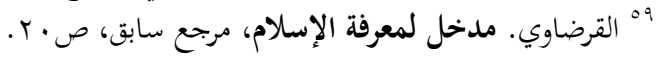




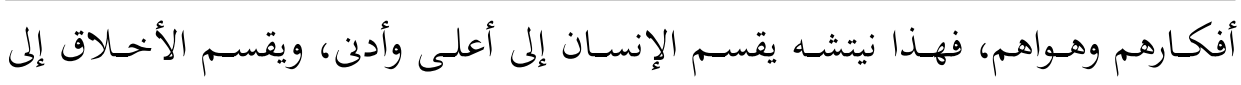

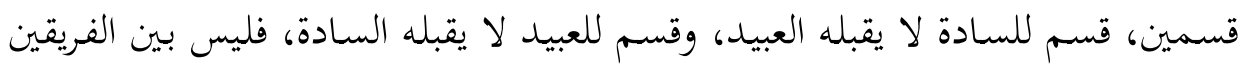

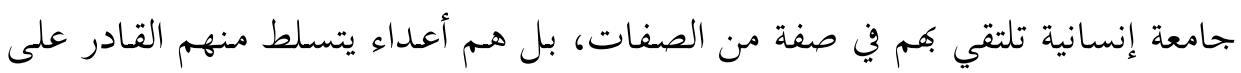

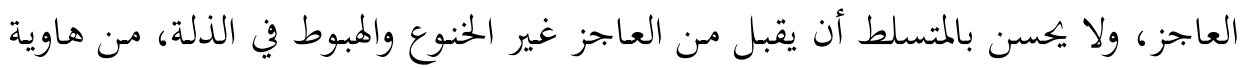

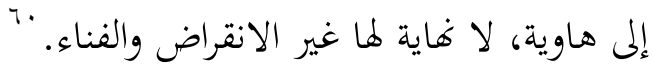

هـ النبوة مصدر كشف النفس البشرية على حقيقتها ومخاطبتها بما يصلحها

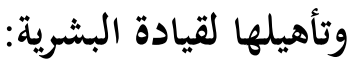

وهنا لا بدّ من معرفة حقيقة الإنسان في طباعه وآماله وتميزه، فحكمة الله تعالى التي

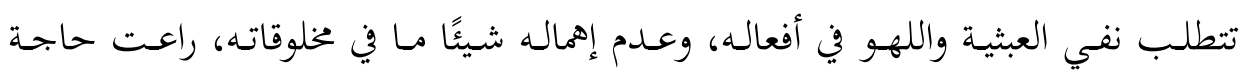

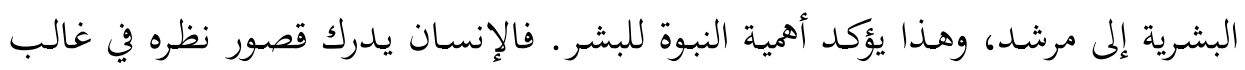

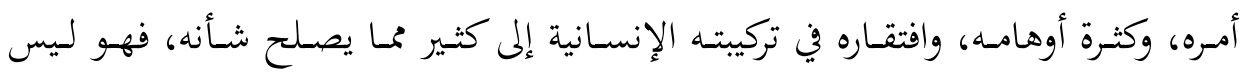

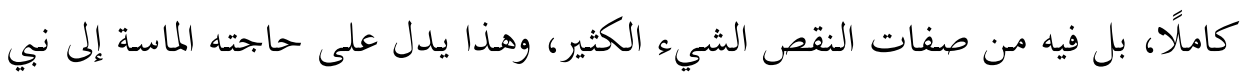

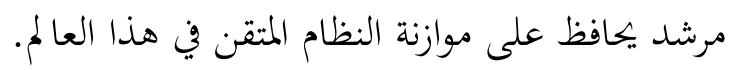

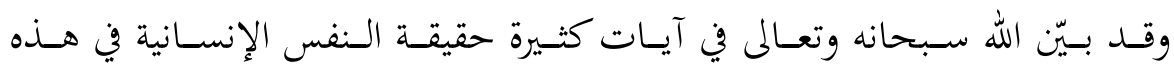

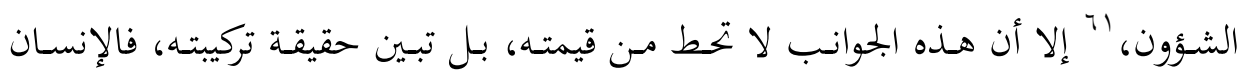

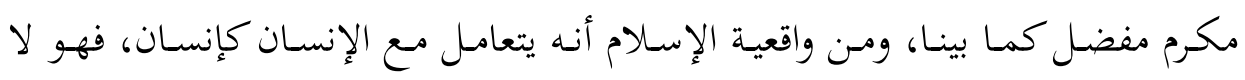

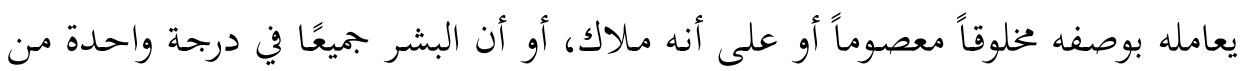

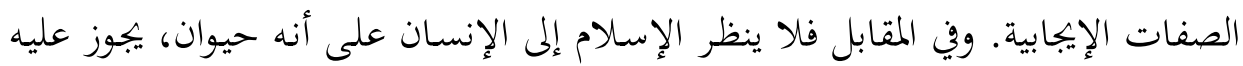

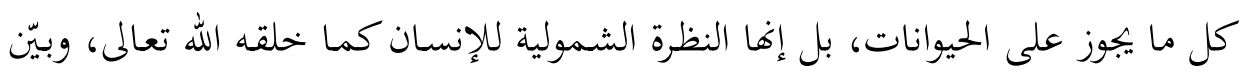

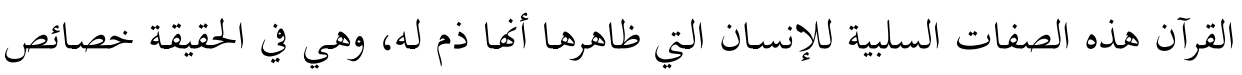
يجب عليه أن يراعيها في شخصيته.

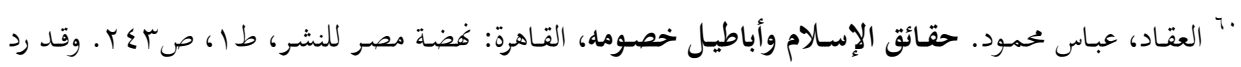

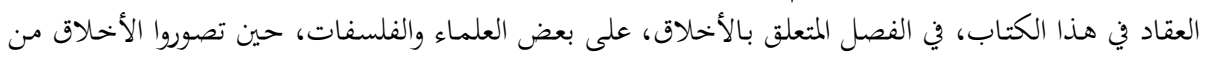

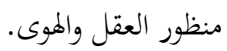

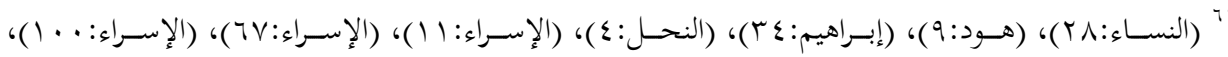

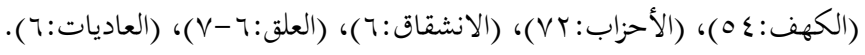




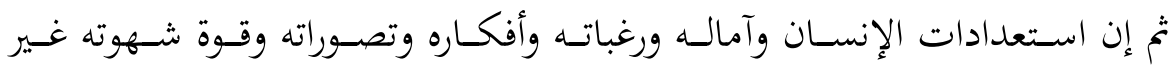

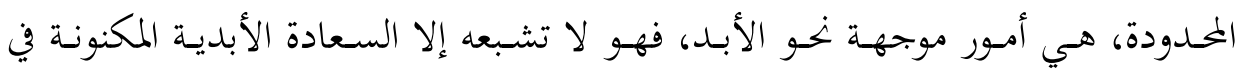

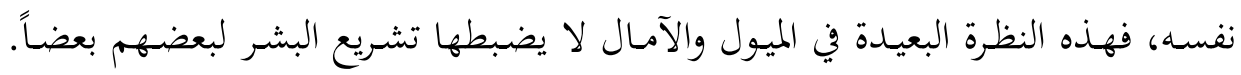

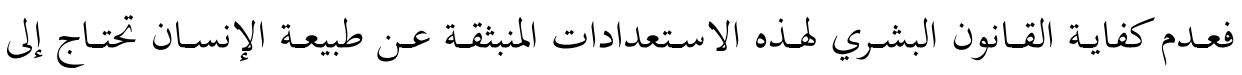

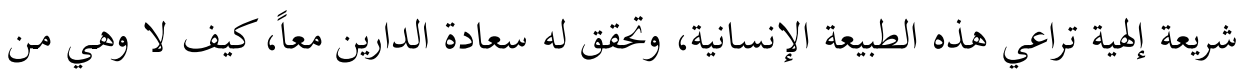

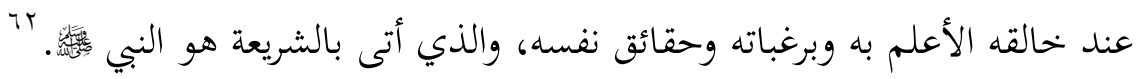
إنه لا بدّ من جولة حقيقية في أعماق النفس الإنسانية، كي نحل تحليلًا دقيقًا ميول

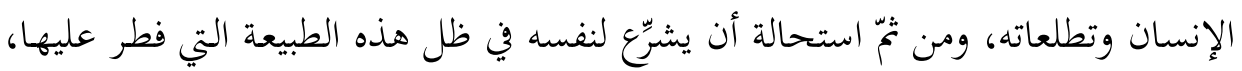

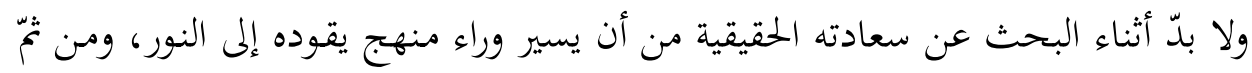

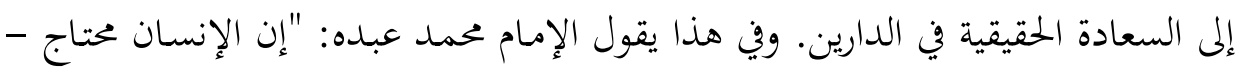

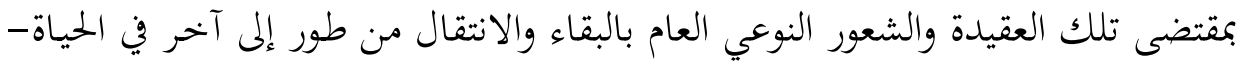

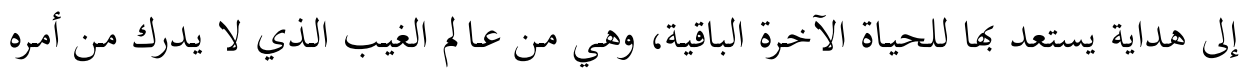

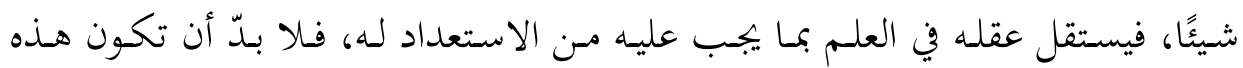

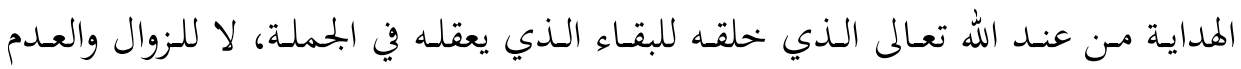

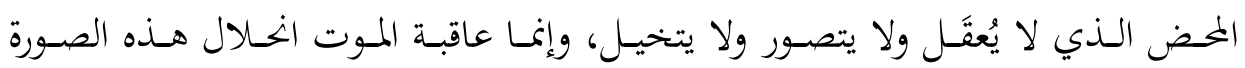

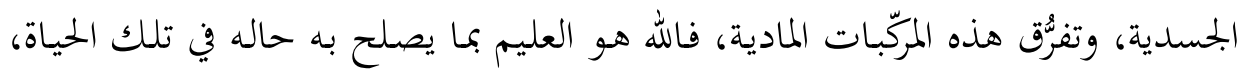

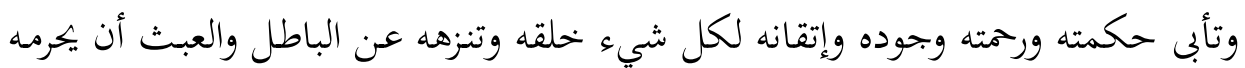

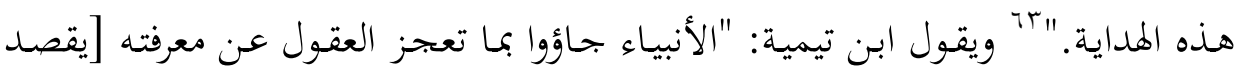

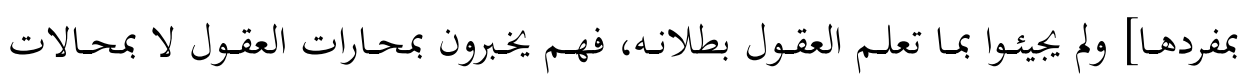

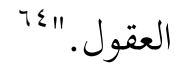

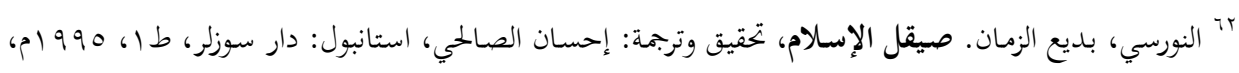

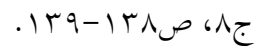

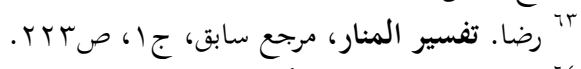

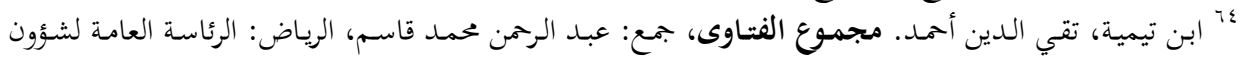

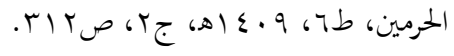




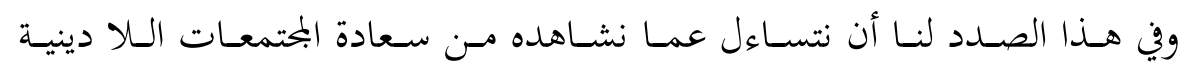

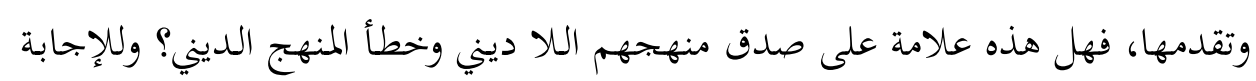

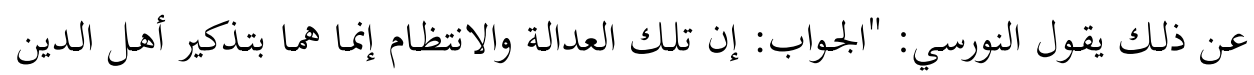

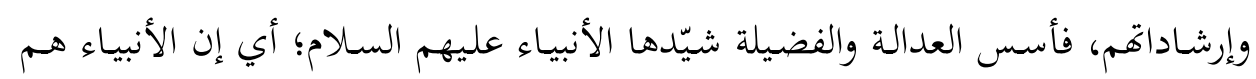

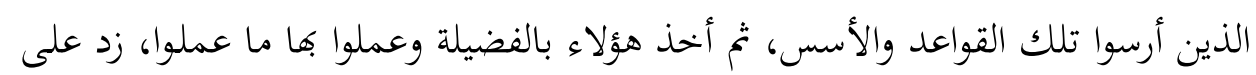

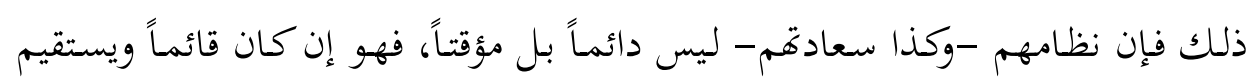

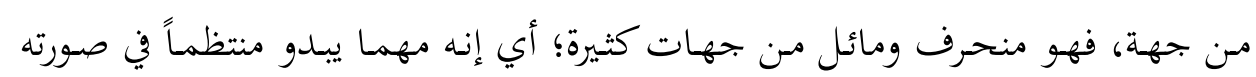

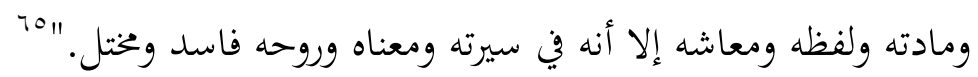

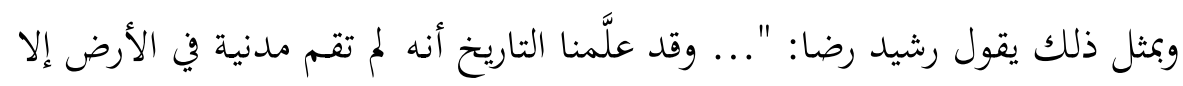

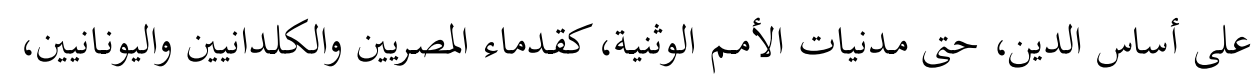

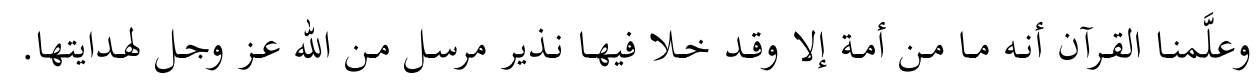

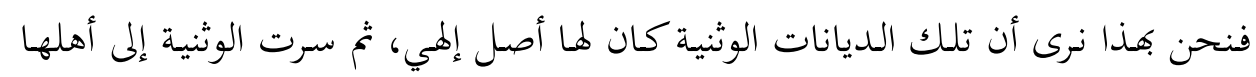

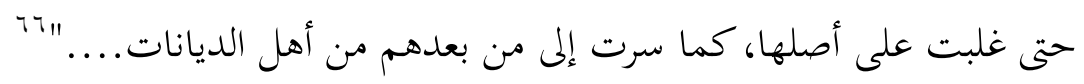

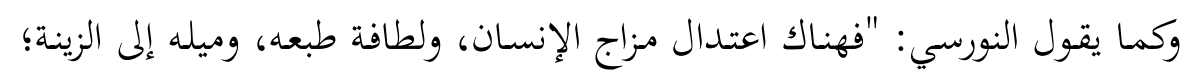

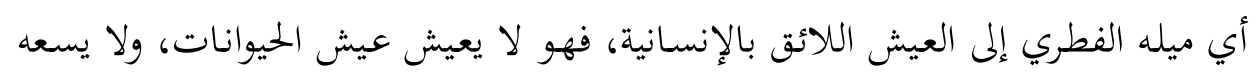

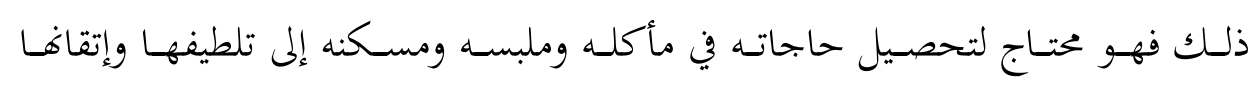

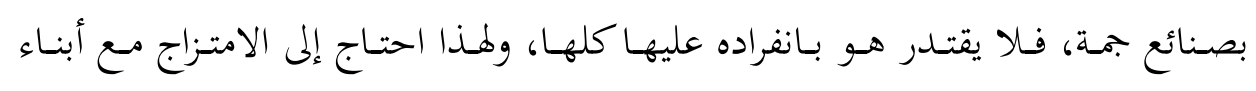

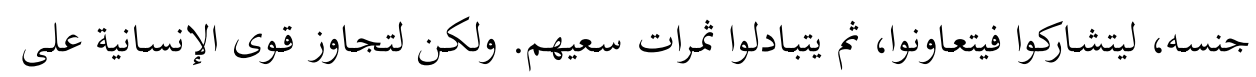

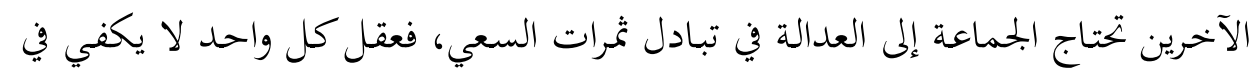

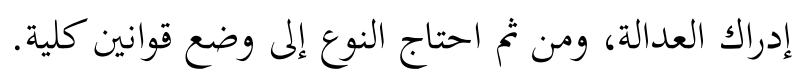

ثم لمحافظة تأثيرها ودوامها، لا بد من مقنن يجريها، ثم لإدامة حاكمية ذلك المقنن في إني

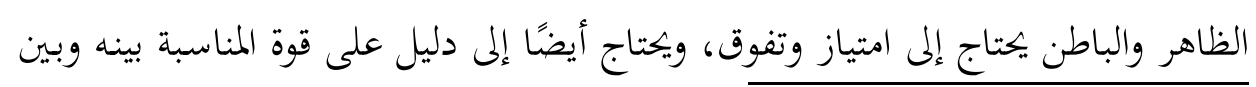

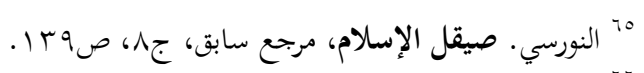

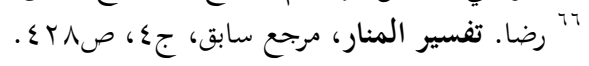




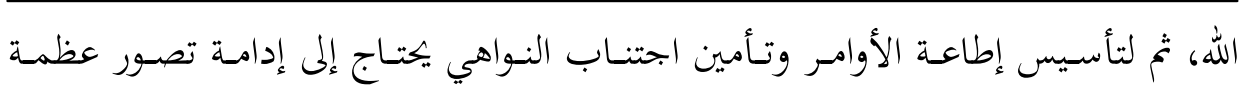
الصـانع وصاحب الملكك في الأذهـان، تم لإدامـة التصور ورسوخ العقائد يحتـاج إلى مُذذكّر

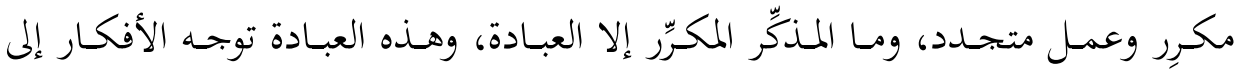
الصانع الحكيم، وهذا التوجه يؤسس الانقياد، والانقياد هو للإيصال إلى النظام الأكمل

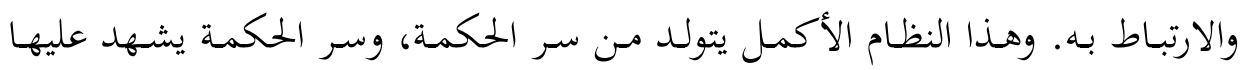

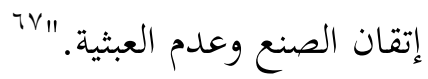

وهي إشـارة واضـحة إلى بتحليـات النبـوة في تحقيـق هـذا الاستقرار. لقــ جعـل أهـل الحلكمة في تصورهم للمثاليات، فملكة معرفة الحقوق التي يراد منها التحسس ماديًا بضرر

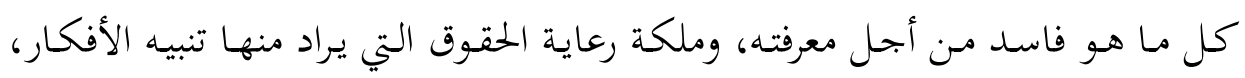

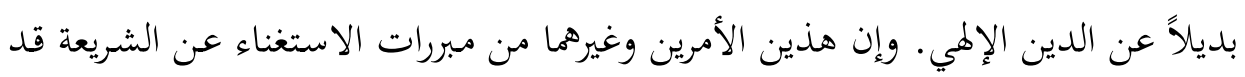

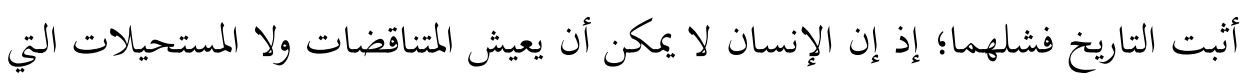
هي فوق طاقته.

وقد ناقش ابن خلدون بعض هذه الجموانب وهو يتحدث عن الإنسان، وأن اجتماع البشر ضرورة لا يمكن الاستغناء عنها، فيتحدث عن الشرع الإلهي والحكمة التي يتوصل

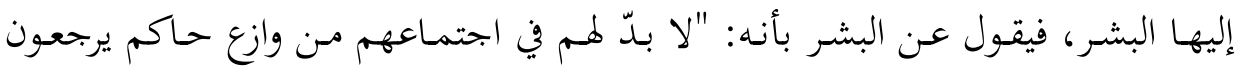

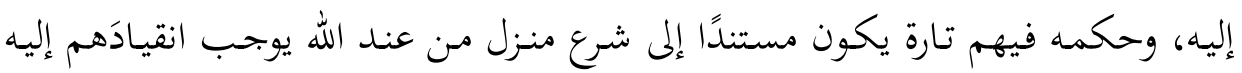

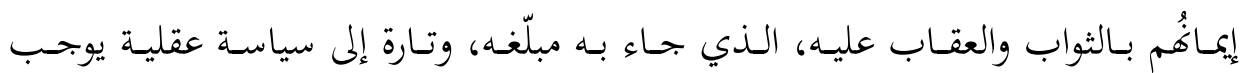
انقيادهم إليها مـا يتوقعونه من ثواب ذلك الحاكم بعد معرفته بمصالحهم، فالأولى يكصل نفعها في الدنيا والآخرة لعلم الشـارع بالمصالح في العاقبـة ولمراعاة بجـاة العباد في الآخحرة،

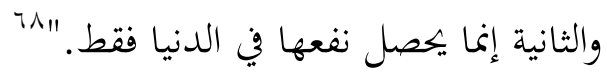

أمـا دور النبوة في قيـادة البشرية وتنظيم أمورهـا، فبإن هـذه المسـألة مـن بـدهيات مـا

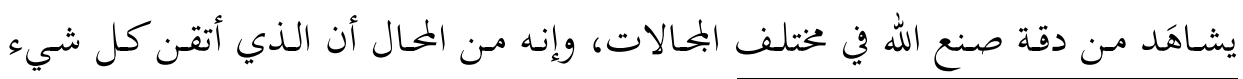

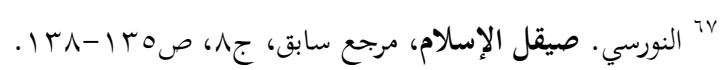

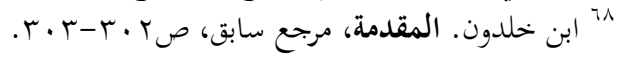




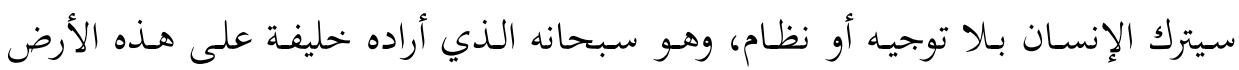

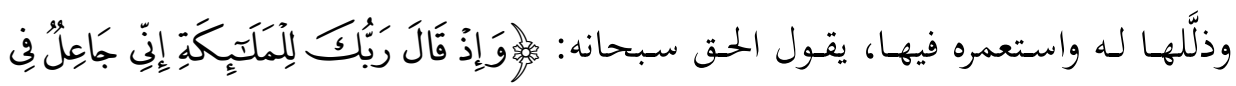

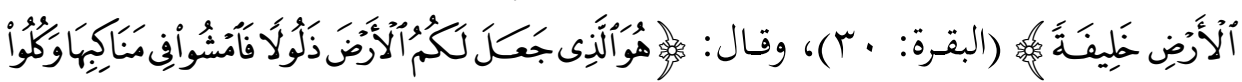

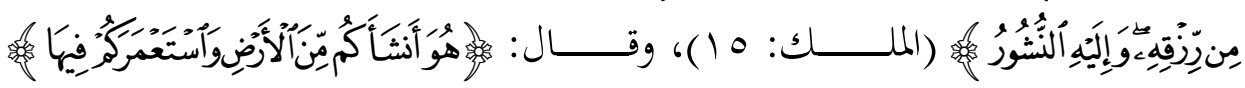

(4): (7)

وفي هذا السياق يورد ابن خلدون كلاماً للحكماء بأن غير الإنسان قد انقاد وانتظم

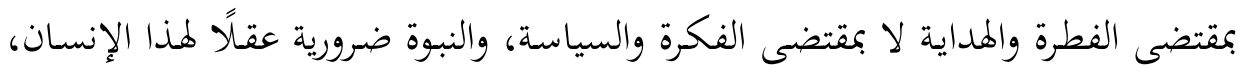

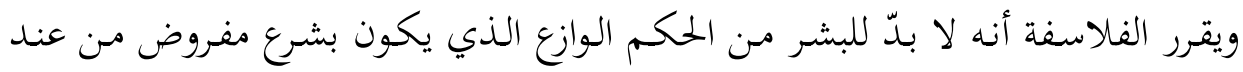

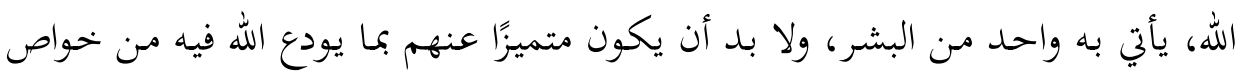
هدايته ليقع التسليم له والقبول منه. 79

ولعل تميز الإنسـان عن غيره إنما هـو بمقتضى التكليف والإرادة التي ركّبها الله في

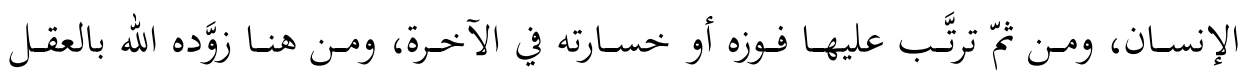

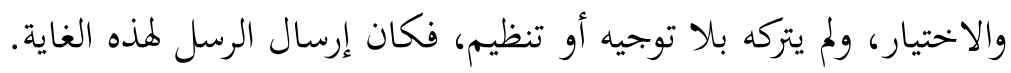

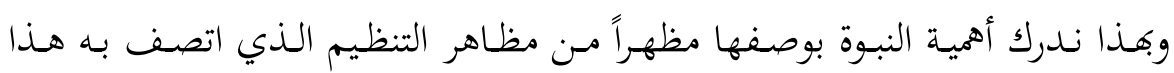

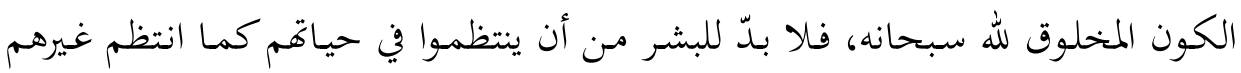

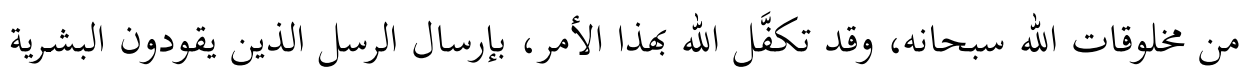

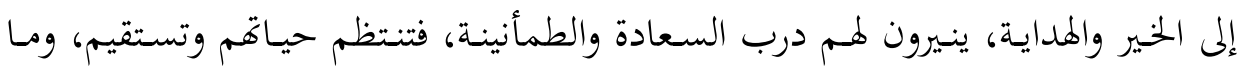

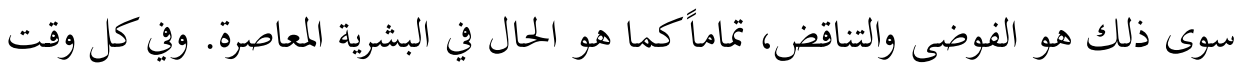

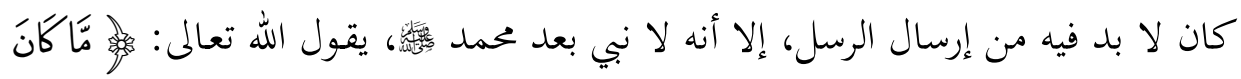

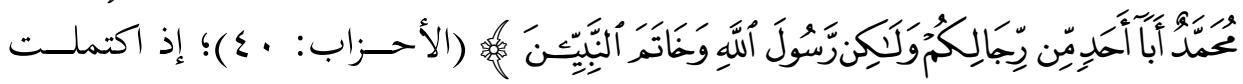
الرسالات به عليه السلام، وشرعه محفوظ من قبل الله تعالى.

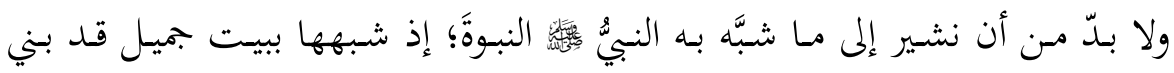

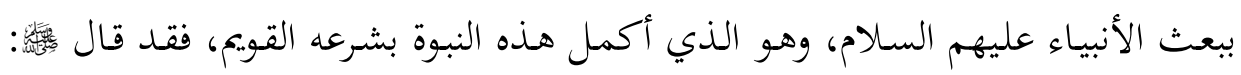




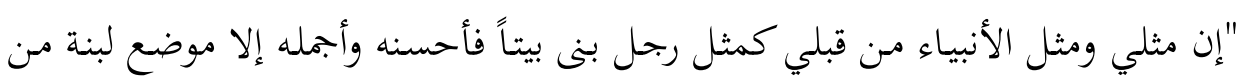

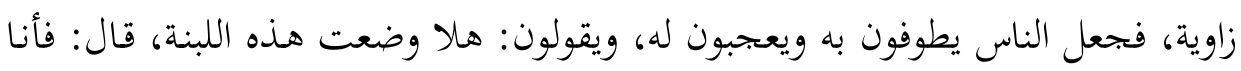

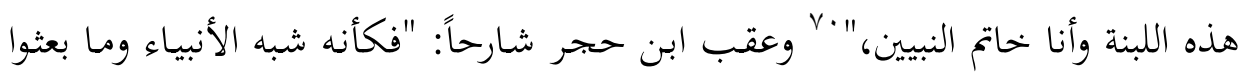

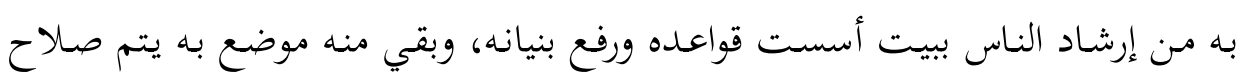

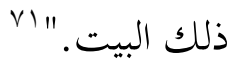

وما أجمل مـا ذكره ابن تيمية في هذا الصـدد؛ إذ يقول: "وحاجـة العبد إلى الرسالة

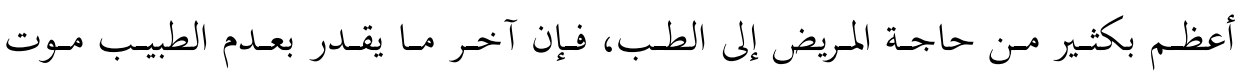

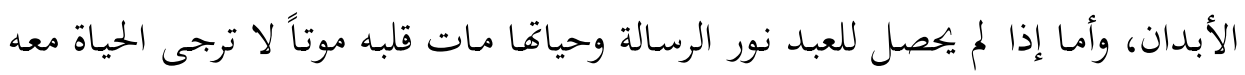

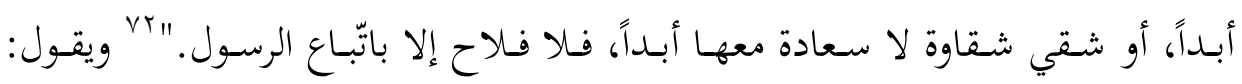

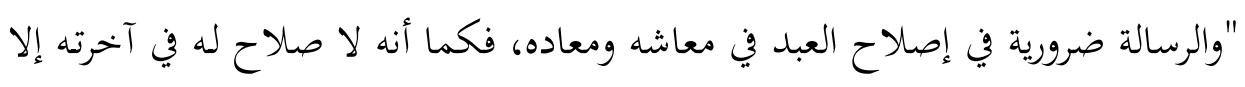

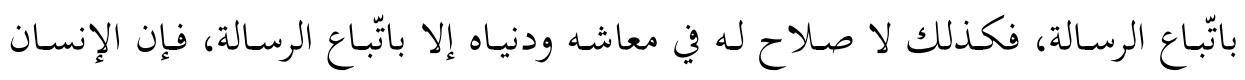
مضطر إلى الشرع، فإنه بين حركتين: حركة يجلب بها ما ينفعه، وحركة يدفع بها ما يضره.

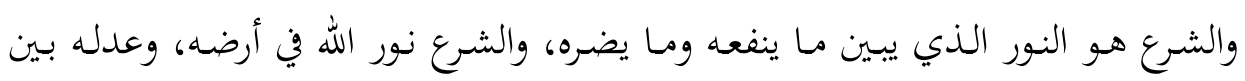
عباده، وحصنه الذي من دخله كان آمناً."Vr"

ولابن القيم أيضًا كلام شبيه بهذا؛ إذ يقول: "ومن هنا تعلم اضطرار العباد فوق كل

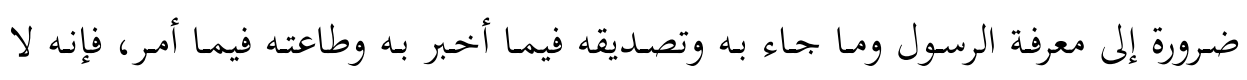

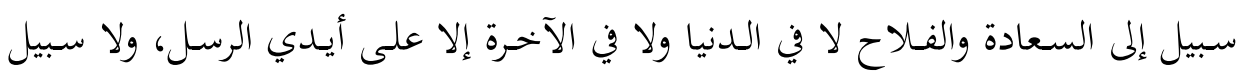

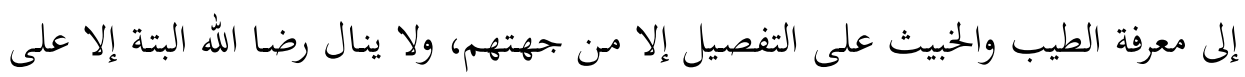

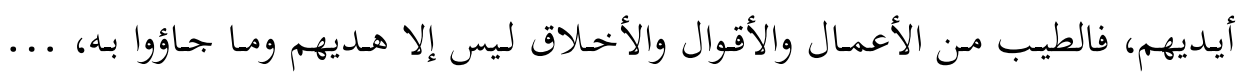

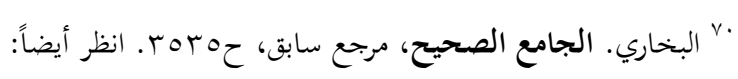

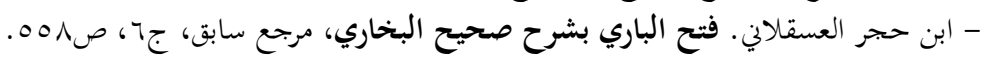

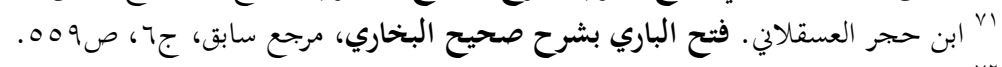

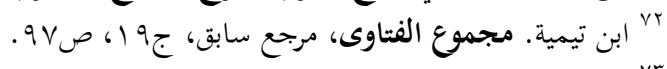

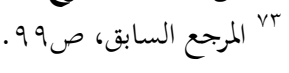


فالضرورة إليهم أعظم من ضرورة البدن إلى روحه، والعين إلى نورها، والروح إلى حياتها،

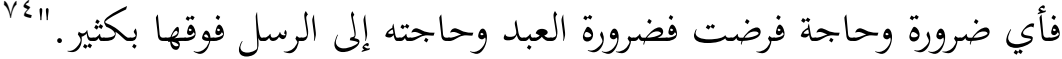

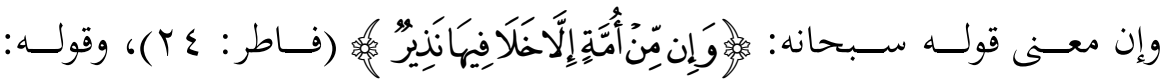

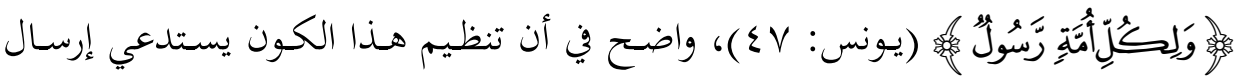

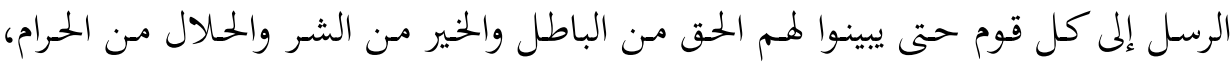
وكل ذلك من لطف الله بعباده في تنظيم هذا الكون وعدم العبثية فيه.

وقد بينت بعض آيات القرآن ضرورة انقياد البشر للأنبياء، فقد قال تعالى:

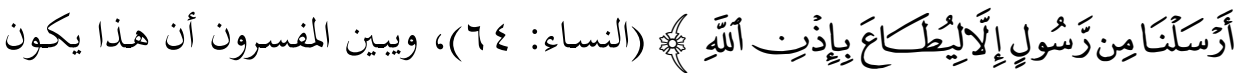

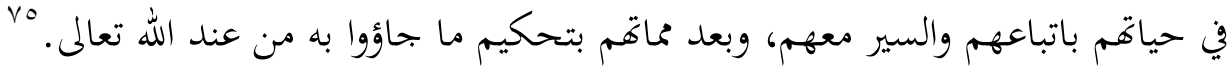

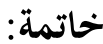

يعد هذا الجههد الذي قمنا به في هذا البحث محاولة لإضافة معرفية في بحال الدراسة الموضوعية الكاشفة عن حديث القرآن الكريع عن النبوة؛ إذ التحليل المقاصدي الذي يراد

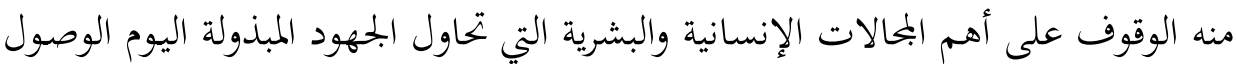
إليها لترشيد غضتها وتقدمها.

وبعد بيان أهمية النبوة وحاجة الناس إليها نخلص إلى الضرورة الملحة في حاجتنا إلى

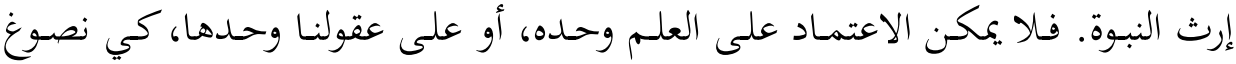
المنهج الأسلم لأنفسنا وللبشرية كلها، من أجل الوصول إلى إلى السعادة الحقيقية في الدارين. وقـد اتضـح لنـا أن هـذا الكـون بمظاهره المختلفـة، قــ أقيم على أسس مـن الدقـة

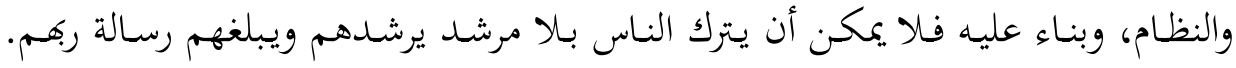

گ`ابن قيم الجوزية. زاد المعاد في هدي خير العباد، تحقيق: حسن المسعودي، بيروت: المكتبة العلمية، طا،

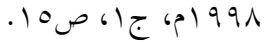

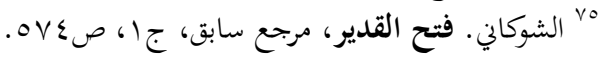


وللرسل دور في إحياء نور المعرفة في عقول النـاس لترشـدهم إلى استخدام حواسهم في

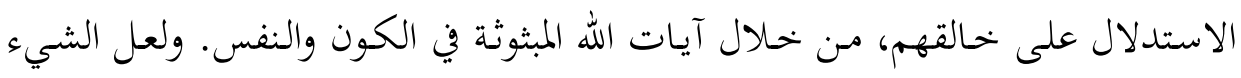

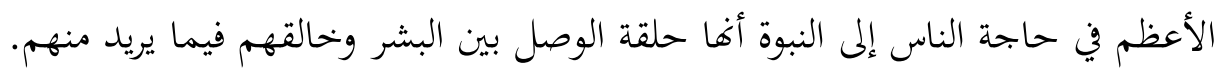
لقد أيد الله الرسل بالمعجزات، وهي وسيلة إلى تقريب الناس إلى أنبيائهم وشدهم

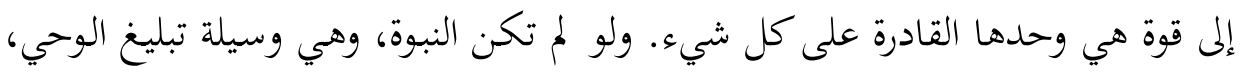

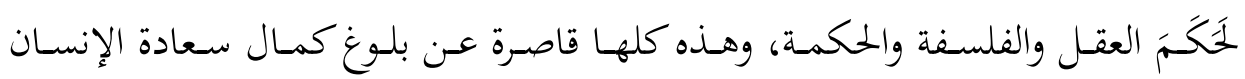
واستقراره.

إن الإنسان مدني في طبعه، ولا يمكنه عزل نفسه عن بني جنسه، ولا بدّ من أخلاق

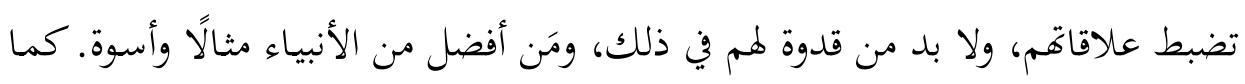

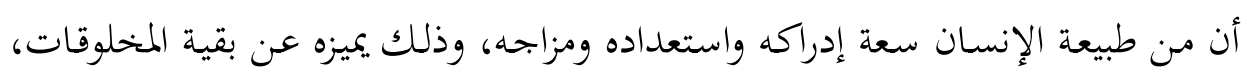

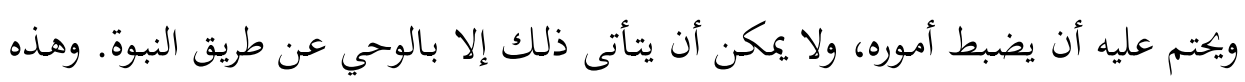

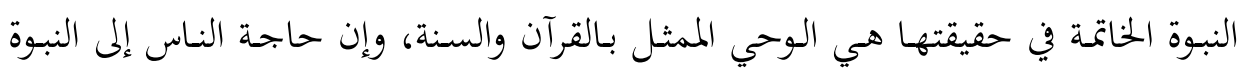
تمثل حاجتهم إلى القرآن والسنة.

بقي أن نقول: هناك بحال مهم تثيره هذه الدراسة ويبقى بحاجة إلى بحث علمي،

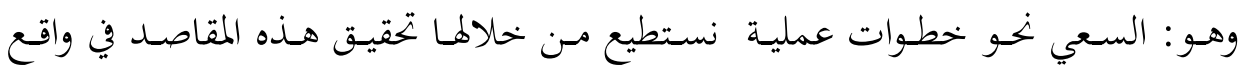

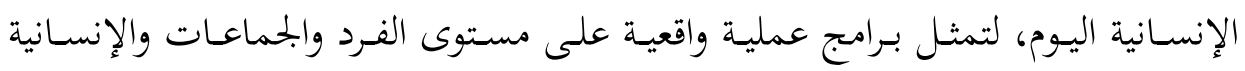
عموماً. 